\title{
Facies, magnetic susceptibility and timing of the Late Devonian Frasnian/Famennian boundary interval (Xom Nha Formation, Central Vietnam)
}

\author{
Hoa Phuong Ta ${ }^{1,2} \cdot$ Peter Königshof ${ }^{3}$ (D) $\cdot$ Brooks B. Ellwood $^{4}$. Thang C. Nguyen ${ }^{5}$. Phuong Lan T. Luu ${ }^{5}$. \\ Dinh Hung Doan ${ }^{6}$. Ariuntogos Munkhjargal ${ }^{3,7}$
}

Received: 1 February 2021 / Revised: 21 June 2021 / Accepted: 8 July 2021 / Published online: 9 September 2021

(C) The Author(s) 2021, corrected publication 2021

\begin{abstract}
Upper Devonian carbonates deposited through the Frasnian/Famennian (F/F) stage boundary in the Xom Nha Formation, Central Vietnam, were studied. The section is mainly composed of fossiliferous, brecciated, and laminated limestone beds, while shale beds occur in a subordinate number. Microfacies generally suggests a hemipelagic setting on an outer shelf environment with low sedimentation rates. A sediment accumulation rate of $0.217 \mathrm{~cm} / \mathrm{kyrs}$ for this section is calculated. The Xom Nha section does not exhibit characteristic black shales or black limestones through the F/F boundary, but instead shows a similar lithology in comparison to other F/F sections in Southeast Asia. The carbonates yielded abundant conodonts, which represent mainly cosmopolitan species but the section differs from most sections in Europe in showing relatively high numbers of Palmatolepis linguiformis species. Deposition through the F/F boundary interval reported here for the Xom Nha section appears to have occurred during a $\sim 1.2 \mathrm{Ma}$, and shows well-defined climate cyclicity.
\end{abstract}

Keywords Microfacies $\cdot$ Conodonts $\cdot$ Magnetic susceptibility $\cdot$ Late Devonian events $\cdot$ Milankovitch cycles

\section{Introduction}

The Late Devonian Frasnian/Famennian (F/F) boundary interval records one of the most important biotic crisis, interpreted to be one of the big five mass extinction events in Earth's history (McLaren 1982; Raup and Sepkoski 1982; McGhee 1996;
Stanley 2016). Numerous publications have shown that many Late Devonian fossil groups were impacted including trilobites, brachiopods, ostracods, ammonoids and tentaculitoids and even specific fossil communities such as coral reef ecosystems (Stearn 1987; Copper 2002; Ma et al. 2002; Olempska 2002; Racki 2005; Bond 2006; Wei et al. 2012; Crônier and François 2014;

1 University of Science, Vietnam National University, Hanoi (VNU), 334 Nguyen Trai, Thanh Xuan, Hanoi, Vietnam

2 Institute of Palaeontology, Hanoi, Vietnam

3 Senckenberg - Research Institute and Natural History Museum, Frankfurt am Main, Germany

4 Department of Geology and Geophysics, Louisiana State University, E235 Howe-Russell Geoscience Complex, Baton Rouge, LA 70803, USA

Thang C. Nguyen
thang0405@gmail.com

Phuong Lan T. Luu

luuphuonglan@gmail.com

Dinh Hung Doan

doandinhhung@gmail.com

Ariuntogos Munkhjargal

ariuka.munkhjargal@senckenberg.de
Department of Geomagnetic Institute of Geophysics, Vietnam Academy of Science and Technology, Hanoi, Vietnam

6 Vietnam National Museum of Nature, Vietnam Academy of Science and Technology, 18 Hoang Quoc Viet, Cau Giay, Hanoi, Vietnam

7 Mongolian University of Science and Technology, 8th khoroo, Baga Toiruu 34, Sukhbaatar District, Ulaanbaatar 14191, Mongolia 
Ma et al. 2016; Mottequin and Poty 2016). The F/F interval is generally characterised by two dark, organic-rich lithologies that were dependent on the facies setting (Carmichael et al. 2019). These are known as the Lower and Upper Kellwasser events (LKE, UKE) that represent a stepwise ocean anoxia and extinction sequence (Walliser 1996; Gerecke and Schindler 2012). The section described herein lacks the diagnostic Kellwasser type lithologies. Here, the LKE took place during the Palmatolepis rhenana conodont zone of the late Frasnian, while the UKE is associated with the F/F boundary (Palmatolepis linguiformis conodont zone; Ziegler and Sandberg 1990). Even though numerous studies on more than 150 Kellwasser localities worldwide have been published, causes and mechanisms for the Late Devonian mass extinctions are still being debated. These events have been linked to an extraterrestrial impact (McGhee 1996; Wang et al. 1996), glaciation (Streel et al. 2000; Song et al. 2017), a cooling event that was linked with abrupt warming and sea-level rise (Thompson and Newton 1988; Algeo and Scheckler 1998; Riquier et al. 2005, 2006; Algeo and Scheckler 2010; Huang et al. 2018b), multiple arc volcanic events (Racki et al. 2018), and eutrophication and the development of suboxic to anoxic conditions present during both events as a result of high biological productivity (Algeo and Scheckler 2010; Whalen 2015; Carmichael and Kido 2014, Carmichael et al. 2016). Possible causes and triggers for anoxia and extinction of Late Devonian events were recently reviewed by Carmichael et al. (2019). These authors documented that the current knowledge concerning the F/F crisis is limited by a significant sampling bias, due to the fact that most previous studies sampled epicontinental seaways or passive continental shelves, primarily from localities across Europe and North America. Recently, more data on the F/F interval were published from southeast Asia (e.g. Huang and Gong 2016; Königshof et al. 2017; Huang et al. 2018a, b; Komatsu et al. 2018; Racki et al. 2019). Here, we report new biostratigraphical, sedimentological and magnetic susceptibility records across the F/F boundary interval exposed in the upper part of the Xom Nha Formation, Central Vietnam.

\section{Geological setting}

The F/F boundary is known from two sections in Vietnam. One section is exposed in the Si Phai Pass, Dong Van area (Ha Giang Province) in the northeast, close to the Chinese border (Ta Hoa 2002, 2007; Königshof et al. 2017; Komatsu et al. 2018) and structurally is associated with the South China Block, within the Early Palaeozoic East Bac Bo Intracontinental Orogenic Belt. The other, the Xom Nha section in Central Vietnam (Figs. 1 and 2; Minh Hoa District, Quang Binh Province), belongs to the Indochina Block (Truong Son Belt, Viet Lao basin group; Thanh et al. 2006; Usuki et al. 2009; Trị et al. 2011). The Xom Nha section is exposed in a steep cliff at an entrance of a cave close to the small village of Xom Nha (N 17'48'26,9", E $105^{\circ} 56^{\prime} 41,1^{\prime \prime}$; Figs. 2 and 3).

The calcareous rocks exposed here belong to the upper part of the Xom Nha Formation and we have sampled a $2.6 \mathrm{~m}$ thick section which covers the F/F stage boundary interval. The Xom Nha section is mainly composed of fossiliferous, brecciated and laminated limestones, while shale beds occur in a subordinate number. The lithological characteristics of the $\mathrm{F} / \mathrm{F}$ interval, such as black limestones and black shales known from many sections worldwide, are lacking as a result of facies, as described from other sections in Asia such as from Thailand (Königshof et al. 2012; Racki et al. 2019). The overall fauna is rather scarce in many layers except for conodonts, which occur in large numbers, particularly in the Frasnian part of the section. Conodonts from the sampled section range from the Frasnian Palmatolepis hassi Zone (Ziegler and Sandberg 1990; Ji and Ziegler 1993) to the Famennian Palmatolepis crepida Zone (Spalletta et al. 2017; Fig. 4).

\section{Methods}

Conodont biostratigraphy and microfacies analysis

Forty-six samples for conodont biostratigraphy from the $2.6 \mathrm{~m}$ thick section were processed. Conodont samples weighting 1 to $1.5 \mathrm{~kg}$ were collected from all beds. Some samples were barren or contained a very limited number of conodonts with a lack of zonal index taxa, so that a detailed stratigraphy for the middle Famennian was not possible. Limestones and marls were cleaned and crushed to about $2 \mathrm{~cm}^{3}$ and placed in wide-mesh sieves hung in buckets filled with warm tap water. Formic acid was added until the dilution reached a concentration of about $5 \%$ $\mathrm{HCOOH}$. The process was repeated until samples were dissolved. The fractions $(63 \mu \mathrm{m}, 125 \mu \mathrm{m}, 250 \mu \mathrm{m}$ and $500 \mu \mathrm{m})$ were dried in an oven $\left(\sim 40^{\circ} \mathrm{C}\right)$ and the most promising conodont-sized fractions were separated by using liquid sodium polytungstate. Later, the conodonts were handpicked under a microscope and the most indicative species were photographed using an SEM. Given that it is common practice in highresolution stratigraphic conodont studies, only Pa elements were identified. This is because many Late Devonian to Mississippian multielement reconstructions are still doubtful and incomplete.

Facies and microfacies types (FTs) were mainly compared on the basis of the classical models used by Wilson (1975) and Flügel (2004). In order to get a thorough overview on the section, we used thin sections that are at least $8 \mathrm{~cm} \times 12 \mathrm{~cm}$ in size. These samples were usually collected at $10 \mathrm{~cm}$ intervals, but if necessary shorter intervals were used. Thin sections and conodont samples are stored at Senckenberg-Research Institute and Natural History Museum Frankfurt, Germany, under repository numbers SEM 70851 to SEM 70886 and SEM-XN-LD-01 to SEM-XN-LD-74, respectively. 
Fig. 1 Simplified map of structural units in Vietnam. The studied section belongs to the Truong Son Belt, Central Vietnam (small rectangle, more details are provided in the figure above)

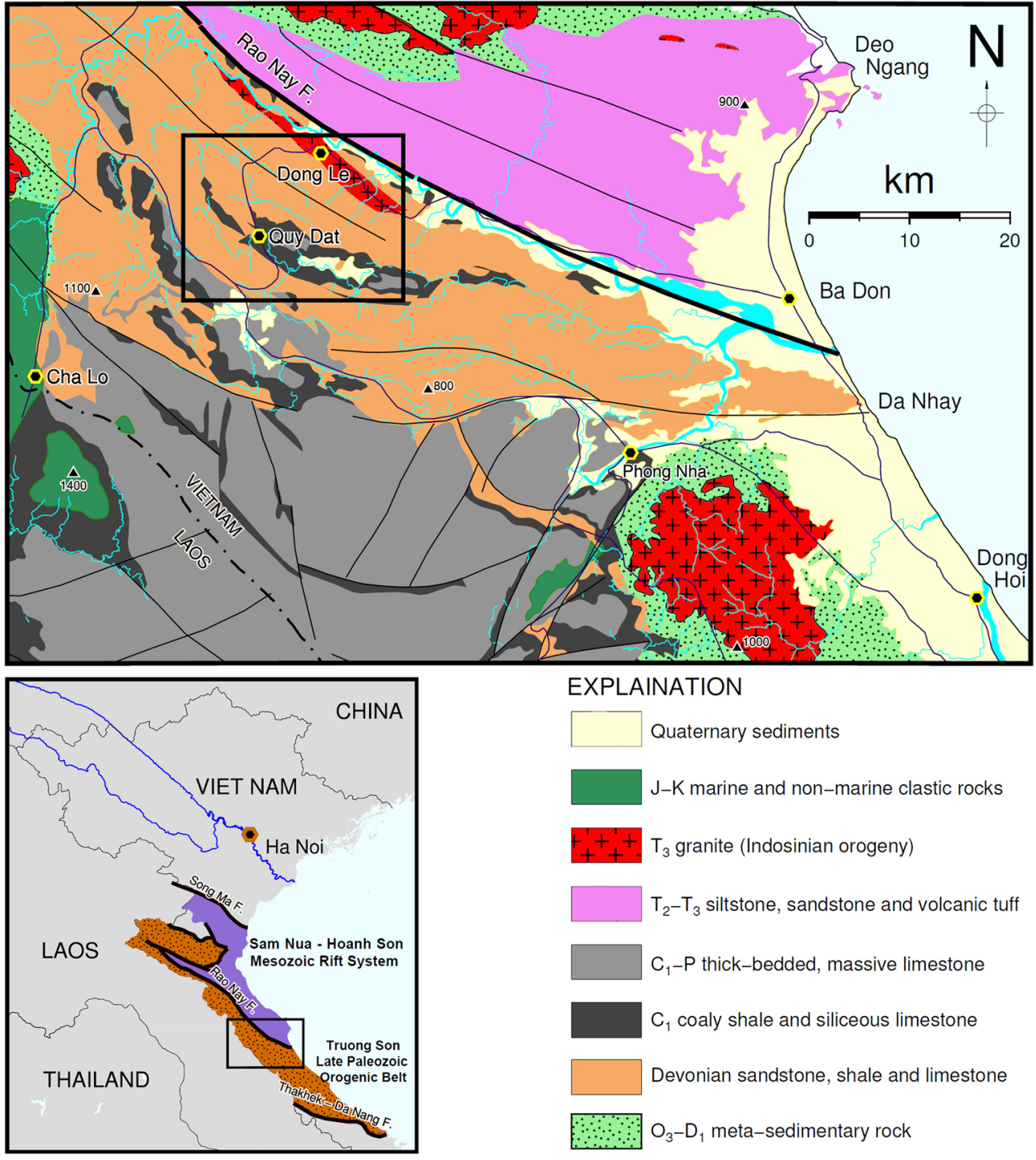

Magnetic susceptibility measurements

From the $2.6 \mathrm{~m}$ thick Frasnian/Famennian Xom Nha section, 132 samples were collected for MS measurements from 24 layers ( $2 \mathrm{~cm} / 1$ sample). Samples for magnetic susceptibility (MS) were measured in the Geomagnetism Department of the Institute of Geophysics laboratory at the Vietnam Academy of Sciences and Technology, Hanoi. The average distance between samples was $2 \mathrm{~cm}$. All materials are "susceptible" to becoming magnetized in the presence of an external magnetic field. Low-field bulk, MS is an indicator of the strength of this transient magnetism (Ellwood and Gose 2006; Ellwood et al. 1995, 1997). MS is very different from remanent magnetism (RM), the intrinsic magnetization that accounts for the magnetostratigraphic polarity variations of materials. MS in stratigraphic sequences is generally considered to be an indicator of detrital iron-containing paramagnetic and ferrimagnetic grains, mainly clay minerals, and can be quickly and easily measured on small friable samples.

\section{Results}

Facies description and depositional environment

The sampled section (Fig. 3) is characterised by greyish wellbedded limestones, which exhibit four different microfacies (MF) types: lime-mudstone to wackestone, (MF 1), grey, fossiliferous wackestone to packstone (MF 2), brecciated grey limestone (MF 3) and alternating grey laminated limestone with marl layers (MF 4).

The overall facies setting points to outer shelf environments below fair-weather wave base. Beside conodonts, distinct layers are fossiliferous and contain tentaculitids, cephalopods, ostracods, trilobites and very rare crinoids and corals. Interestingly, the Xom Nha section does not exhibit characteristic black shales or black limestones around the F/F boundary (Fig. 4a) known from many places around the world, but instead show a similar lithology in comparison to other sections in Southeast Asia, particularly in Thailand and Vietnam (Königshof et al. 2012, 

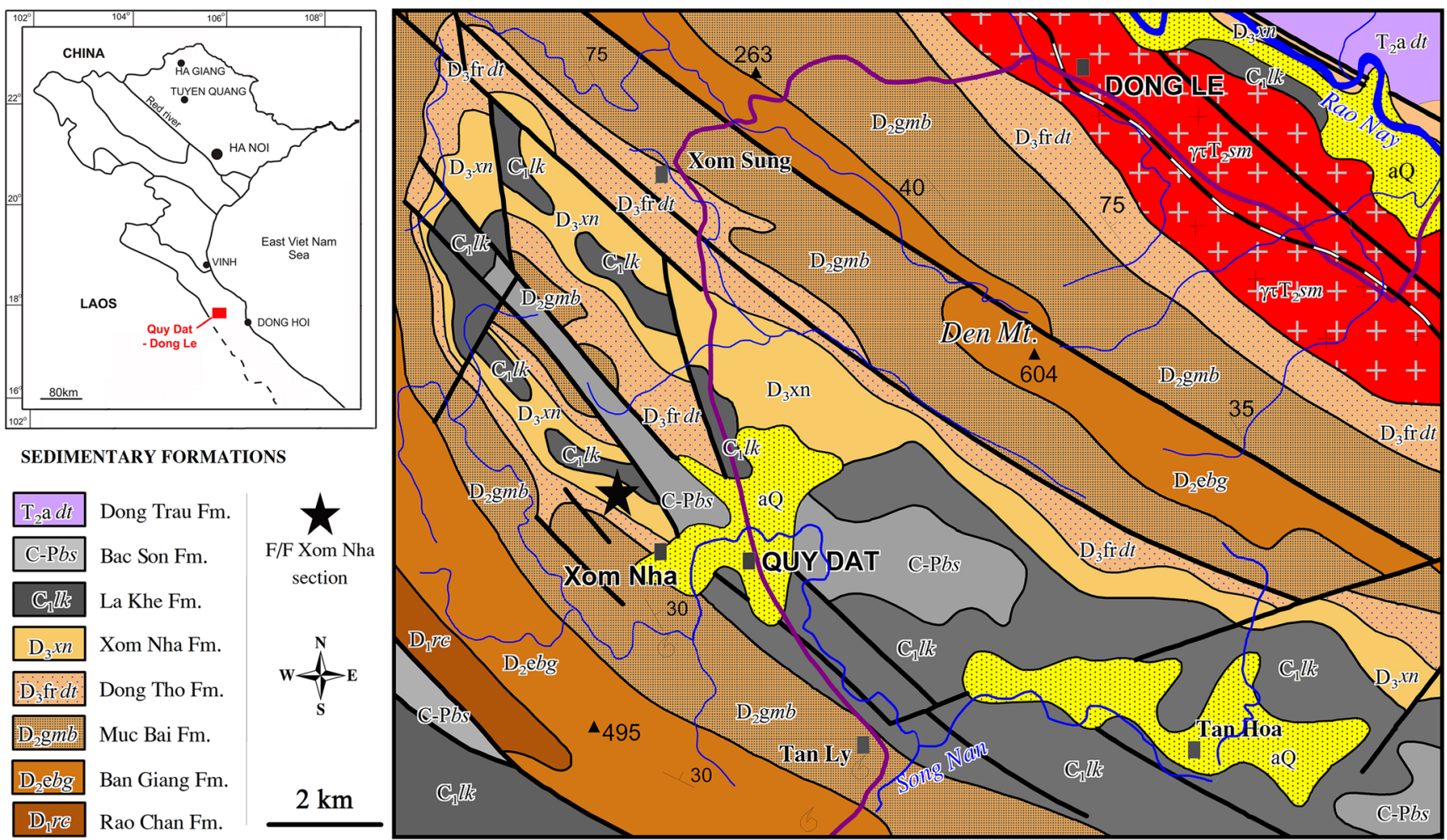

Fig. 2 Location and geological context of the studied section in Central Vietnam (Minh Hoa District, Quang Binh Province). Asterisk marks the position

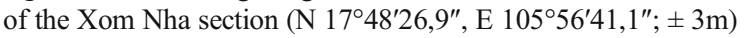

2017; Komatsu et al. 2018; Racki et al. 2019), which point to similar facies settings.

\section{MF 1: microbioclastic lime mudstone to wackestone}

Microfacies 1 occurs in Frasnian limestones and is dominated by greyish, thin-bedded lime mudstone to wackestone at the base of the section (Palmatolepis hassi Zone) and within the linguiformis Zone. The micritic matrix contains rare fossils, including conodonts, tentaculitids, benthic ostracods and small shell hash. In distinct layers, pelagic entomozoaceans also occur. The size of the bioclasts is small, burial solution occurs and some bioclasts are separated by clay seams. Shells are frequently dissolved and filled with sparry calcite. The fossil content generally varies between 5 and $10 \%$. A mottled/nodular fabric occurs, along with styliolitization, but this is less frequent. Rarely, hard ground surfaces occur close to the F/F boundary (Fig. 4b). Similar sedimentological features around the F/F boundary are described from the Mae Sariang section in northwestern Thailand (Königshof et al. 2012).

Interpretation: Hardgrounds are related to a combination of non-deposition or very low sedimentation rates. The overall fine-grained sediment and fossil content suggests a hemipelagic facies setting on an outer shelf environment with low sedimentation rates. The occurrence of pelagic entomozoaceans is restricted to distinct layers. Variable fabric ranging from thinbedded to nodular/mottled can be explained as a result of bioturbation in a low-energy environment.

\section{MF 2: fossiliferous wackestone to packstone}

This rock type is composed of bioclastic wackestone to packstone which frequently occurs in the Palmatolepis rhenana rhenana and Pa. rhenana nasuta zones. Faunal elements comprise mainly conodonts, benthic ostracods, trilobites, tentaculitids, cephalopods and thin-shelled bivalves, which occur in descending order (Fig. 4c, d). Crinoid ossicles and small corals were observed, but occur with less frequency (Fig. 4e). Benthic ostracods are mainly disarticulated, but also complete ones occur. Pelagic ostracods are less frequent. The fossil content is higher than observed in MF 1 and can reach up to $30 \%$. Single layers are packstone and bioturbation occurs in distinct layers. $\mathrm{Fe}-\mathrm{Mn}$ crusts and microstromatolites around bioclasts and lithoclasts are observed in a few thin sections (Fig. 4f); the matrix is composed of lime mud. As a result of transport, the limestones show bedding and gradation, along with small-sized shall hash of up to $3 \mathrm{~mm}$.

Interpretation: This microfacies suggests a hemipelagic setting on an outer shelf environment with low sedimentation rates. Coated clasts can be interpreted as reworked hardground 

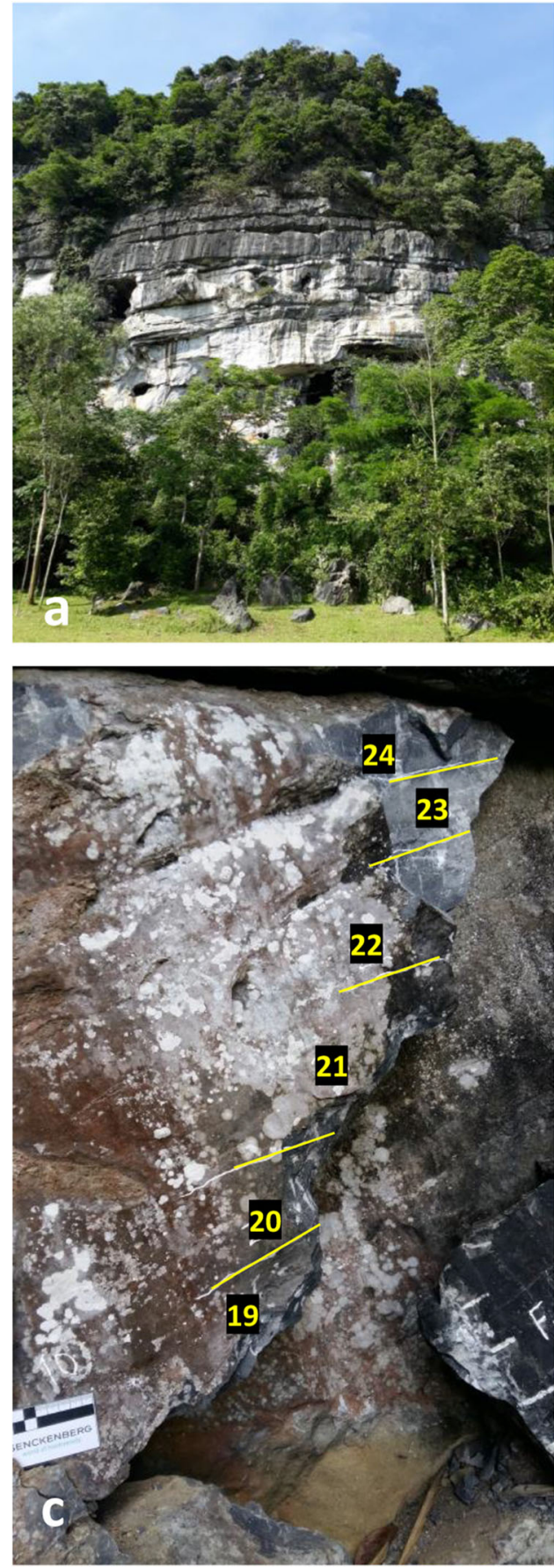

Fig. 3 Field photographs of the Xom Nha Formation bracketing the F/F interval: a limestones of the Len Don mountain and entrance to the cave, b taking samples with a rock saw at the steep cliff, $\mathbf{c}$ monotonous marl and limestone above the F/F boundary, $\mathbf{d}$ details of the F/F boundary within

fragments (Zatoń et al. 2012; Lazar et al. 2013). Shallowwater bioclasts, such as corals, occur in distinct layers, and are very scarce. They occur in samples VN-XN-11 and VN$\mathrm{XN}-12$ (upper $P$ a. rhenana nasuta Zone/Pa. rhenana rhenana Zone), which appear to be linked with a sea-level fall. The increasing number of Icriodus specimens in sample VN-XN11 may support this assumption.
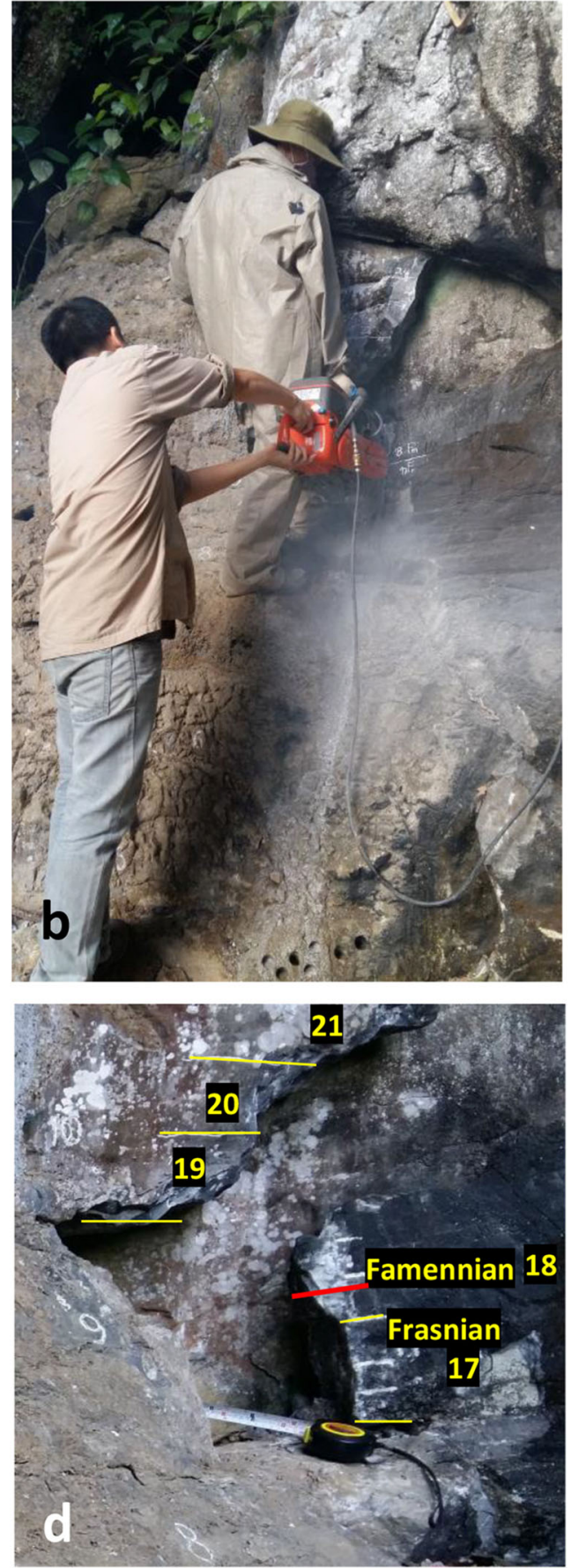

layer 18 (boundary marked in red): sampled beds are shown with yellow numbers; white numbers are from earlier field studies that were correlated with the new sampling in 2017. The F/F boundary is placed within bed 18 (18b contains the first conodont Palmatolepis triangularis)

\section{MF 3: brecciated grey limestone}

This facies type occurs in distinct layers within the Xom Nha section, and fauna is rare or absent. These limestones are characterised as a monomict stylobreccia (Fig. 4g). Another type of carbonate breccias occurs in the linguiformis Zone (sample VN-XN-17a) and exhibits strong fracturing of 

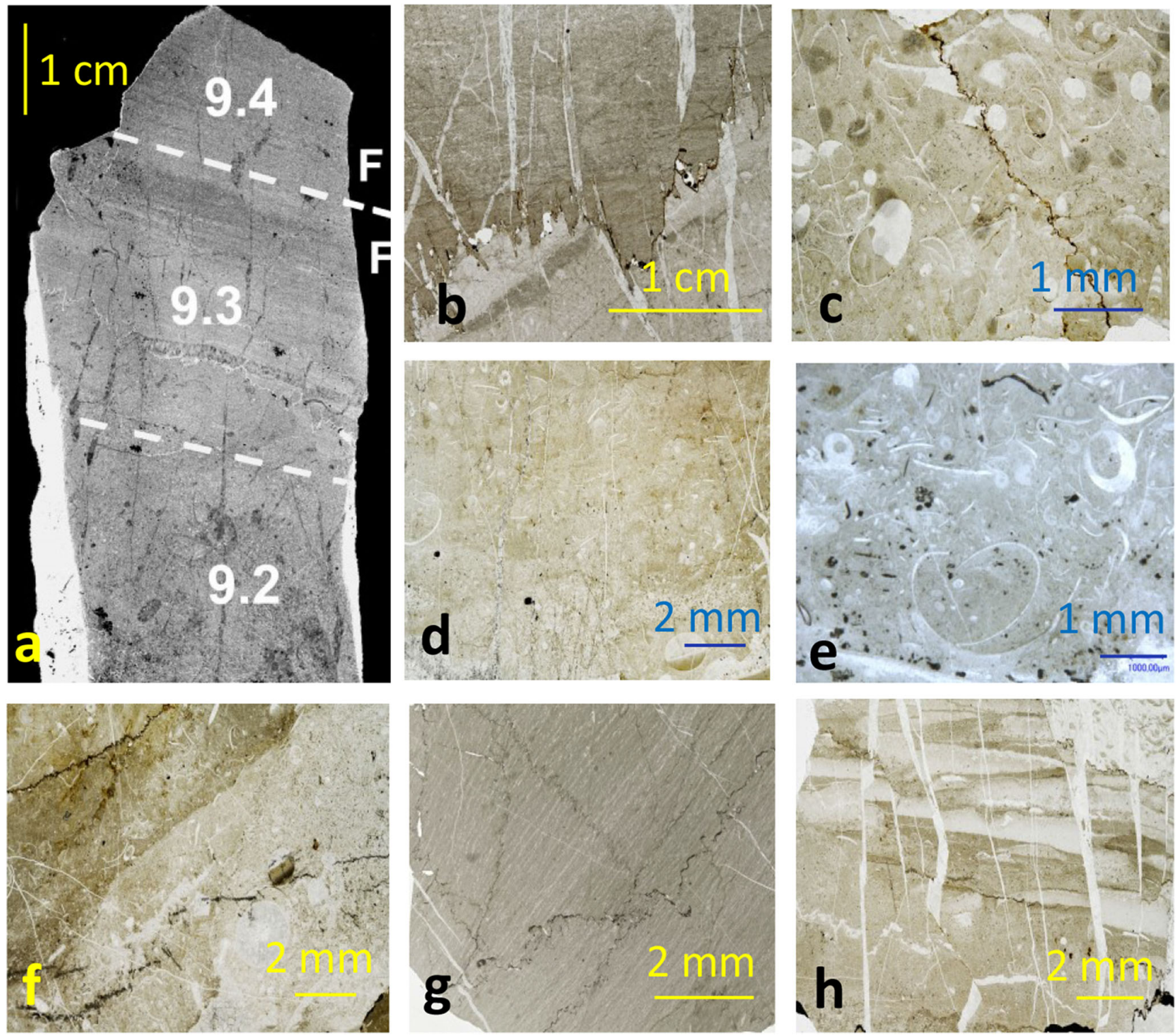

Fig. 4 a detail of the Frasnian/Famennian (F/F) boundary: microbioclastic wackestone is overlain by laminated limestone (vertical cross-section; numbers on the slab are a result of an older field campaign), no black shales or black limestone occur; $\mathbf{b}$ parallel-laminated lime mudstone overlying a wackestone; hardgrounds are characterised by a stepped escarpment on top of the hardground, forming a palaeorelief which is sometimes covered by a dark crust (manganese oxides) of variable thickness, sample VN-XN-18a, linguiformis Zone (equivalent of the Upper Kellwasser Limestone); c wackestone within the Palmatolepis rhenana rhenana Zone; bioclasts are preferably ostracods (some pelagic entomoceaceans with characteristic spines (upper left side) and cephalopods; sample VN-XN-15a, Pa. rhenana rhenana Zone; $\mathbf{d}$ microbioclastic wackestone with shell hash (mainly ostracods) and rare echinoderm ossicles, sample VN-XN-12, base of Pa. rhenana rhenana Zone; e bioclastic wackestone with coated bio- and lithoclasts; f wackestone with ostracod, cephalopod, trilobite and rare echinoderm and coral fragments, in sample VN-XN-11, Palmatolepis rhenana nasuta Zone; $\mathbf{g}$ beginning of a monomict stylobreccia as a result of pressure solution; $\mathbf{h}$ tectonic fault breccia, sample VN-XN-17a individual clasts as well as the whole rock. Microfractures differ in width and are filled with sparry calcite (Fig. 4h).

Interpretation: Whereas the monomict stylobreccia is a result of pressure solution of lime mudstones, the second rock type is interpreted as a tectonic fault breccia.

\section{MF 4: alternating grey limestone with marl layers}

This microfacies occurs mainly in the Famennian part of the Xom Nha section and shows an alternation of laminated lightgrey limestone and intercalated greyish marls. The marls are less frequent. These limestones and marls yielded rare fauna following the Upper Kellwasser Event. Occasionally, thin 


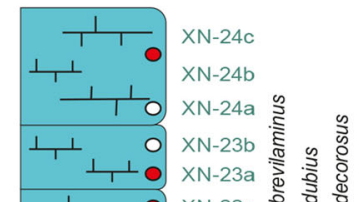

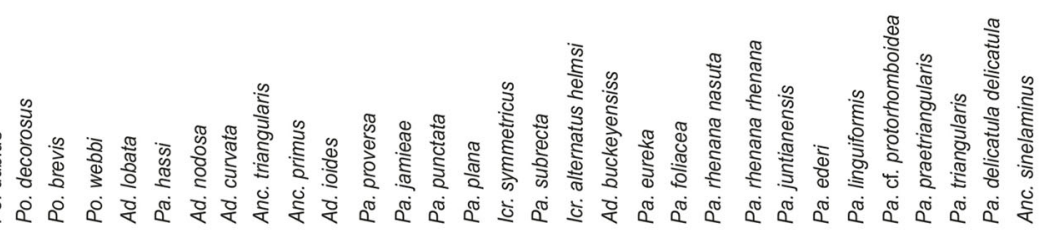
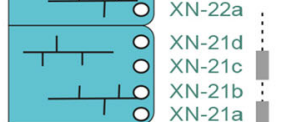

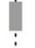

${ }_{1,1}^{1}, 0 \begin{aligned} & x N-21 a \\ & X N-20 b \\ & X N-20\end{aligned}$

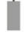

$1 \quad 1$

$\stackrel{1,1}{\perp} \mathrm{ON}-19 \mathrm{~b}$

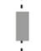

1

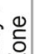

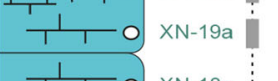

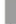

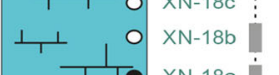

i

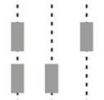

$+$

1

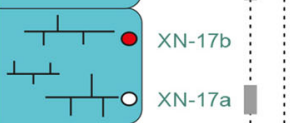

il i i

i i i

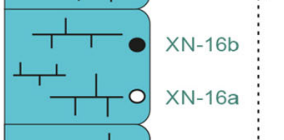

i i i

1

$\underset{+, 1}{1}+{ }_{1}^{1} \times \mathrm{N}-15 \mathrm{~b}$

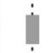

in

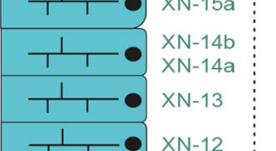

1 i i i i

11

iोi iोi iो

in

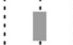

प U

$\frac{\frac{1}{1}}{\frac{1}{1}}$

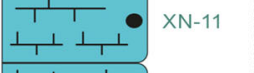

$\div$

i i

:

1

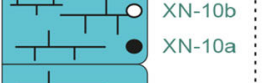

11

4

4

in

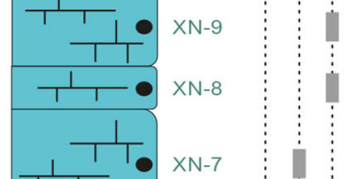

4

i

i

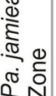

i

1

i

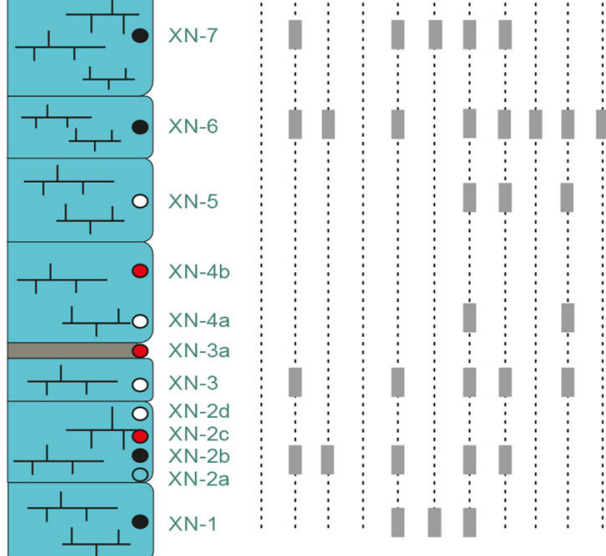

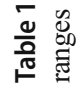




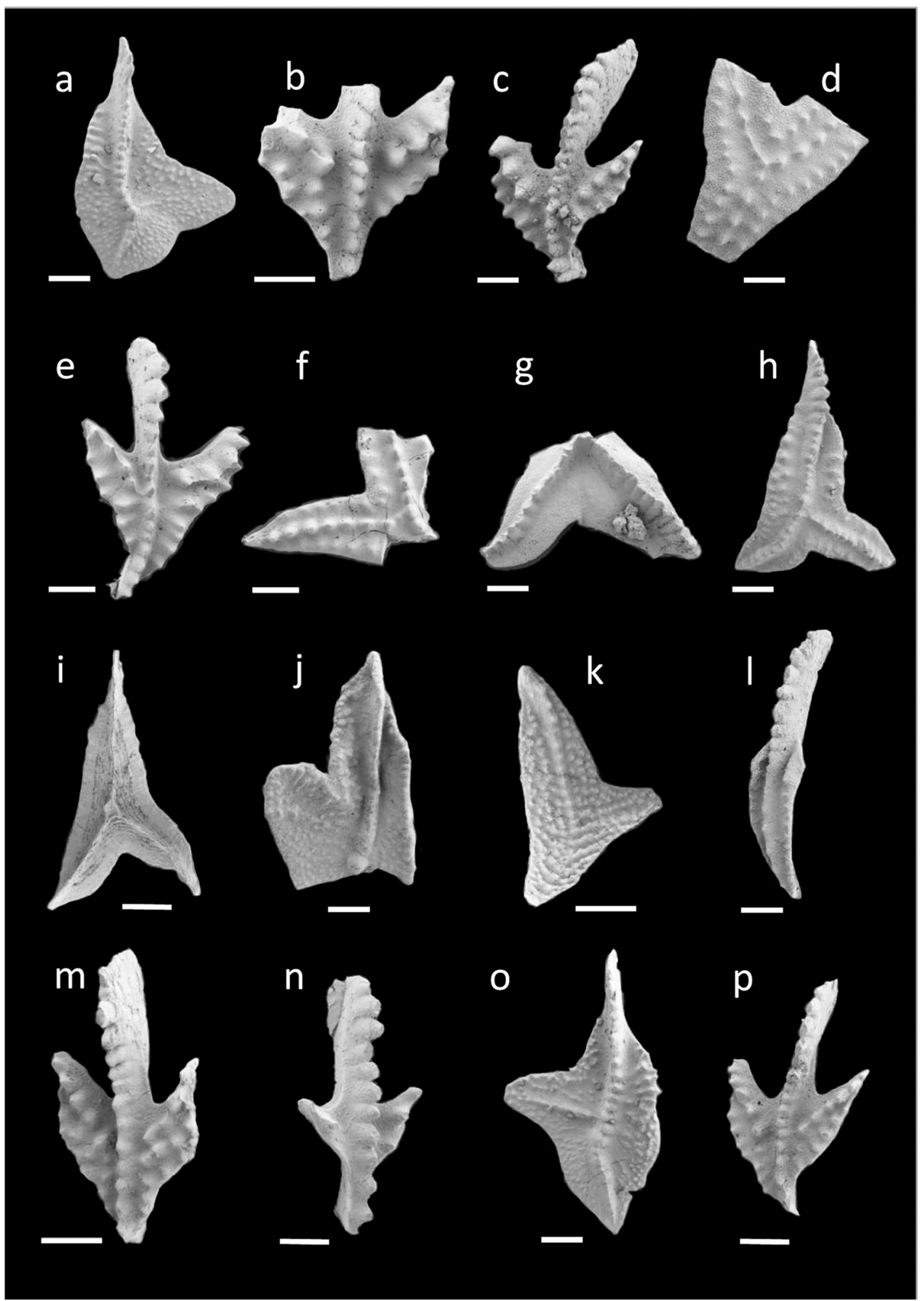

Fig. 5 Important conodonts of the Xom Nha section (scale bares $=100$

$\mathrm{VN}-\mathrm{XN}-6$ ); i Ancyrognathus triangularis (lower view, sample VN-XN6); j Palmatolepis proversa (sample VN-XN-6); k Ancyrognathus aff. asymmetricus (sample VN-XN-6); I Polygnathus decorosus (sample VN-XN-8); m Ancyrodella nodosa (sample VN-XN-8); n Ancyrodella ioides (sample VN-XN-8); o Palmatolepis gigas gigas (sample VN-XN6); Ancyrodella nodosa (sample VN-XN-8) (sample VN-XN-2); c Ancyrodella nodosa (sample VN-XN-2); Ancyroides cf. leonis (broken specimen; sample VN-XN-3); e Ancyrodella nodosa (sample VN-XN-2); f Ancyrognathus triangularis (broken specimen, sample VN-XN-3); g Ancyrognathus primus (broken specimen, sample VN-XN-5); h Ancyrognathus triangularis (sample 


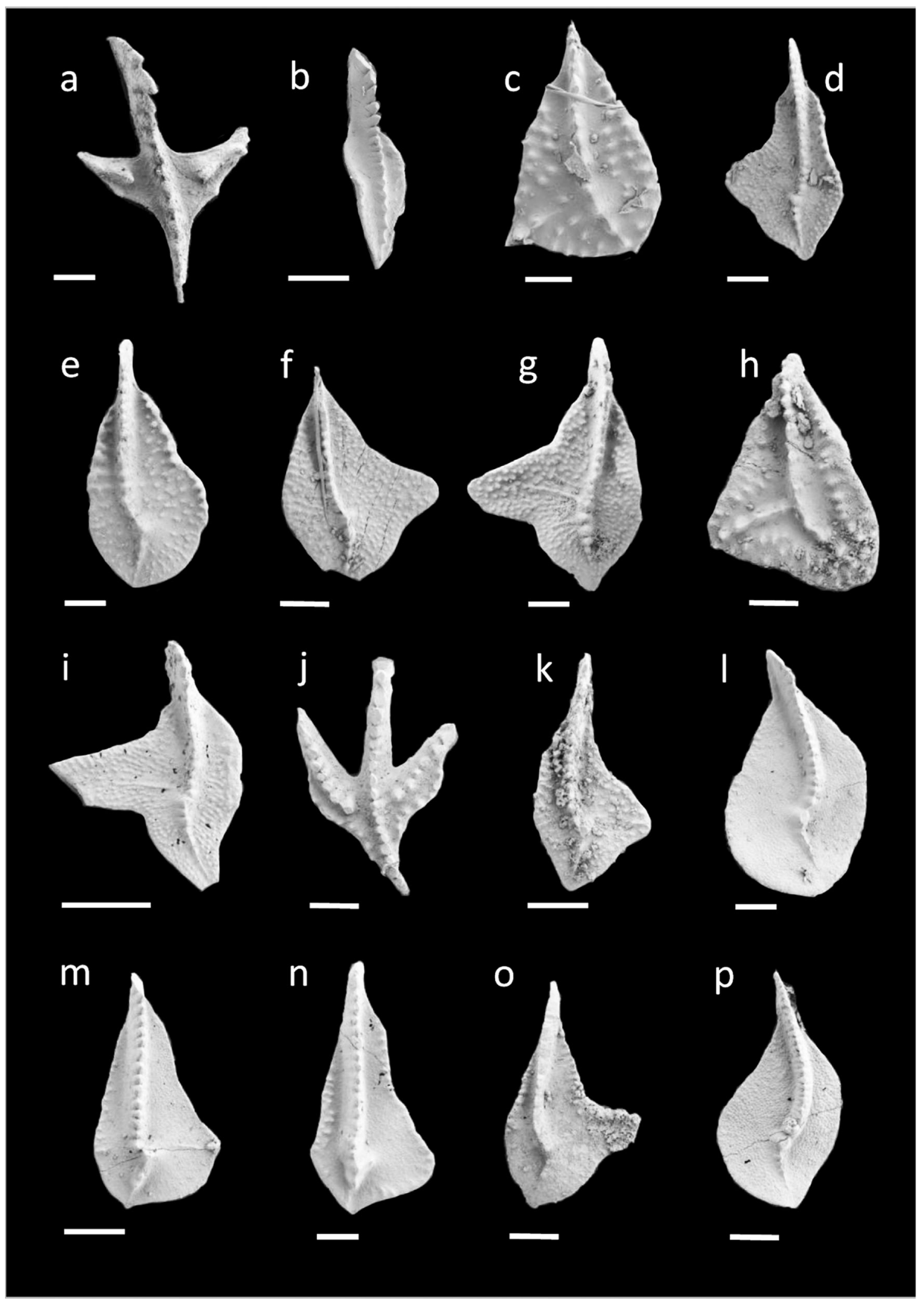

Fig. 6 Important conodonts of the Xom Nha section (scale bares $=100$ $\mu \mathrm{m})$ : a Ancyrodella ioides (sample VN-XN-9); b Polygnathus decorosus (sample VN-XN-11); c Ancyrognathus seddoni (sample VN-XN-11); d Palmatolepis unicornis (sample VN-XN-11); e Palmatolepis cf. foliacea (sample VN-XN-11); f Palmatolepis cf. hassi (sample VN-XN-11); g Palmatolepis subrecta (sample VN-XN-13); h Ancyrognathus seddoni (sample VN-XN-12); i Palmatolepis rhenana rhenana (sample VN$\mathrm{XN}-12)$; j Ancyrodella nodosa (sample VN-XN-13); k Palmatolepis subrecta (sample VN-XN-14); I Palmatolepis eureka (sample VN-XN13); m Palmatolepis juntianensis (sample VN-XN-13); n Palmatolepis juntianensis (sample VN-XN-14); o Palmatolepis subrecta (sample VN$\mathrm{XN}-15$ ); p Palmatolepis ederi (sample VN-XN-15) 


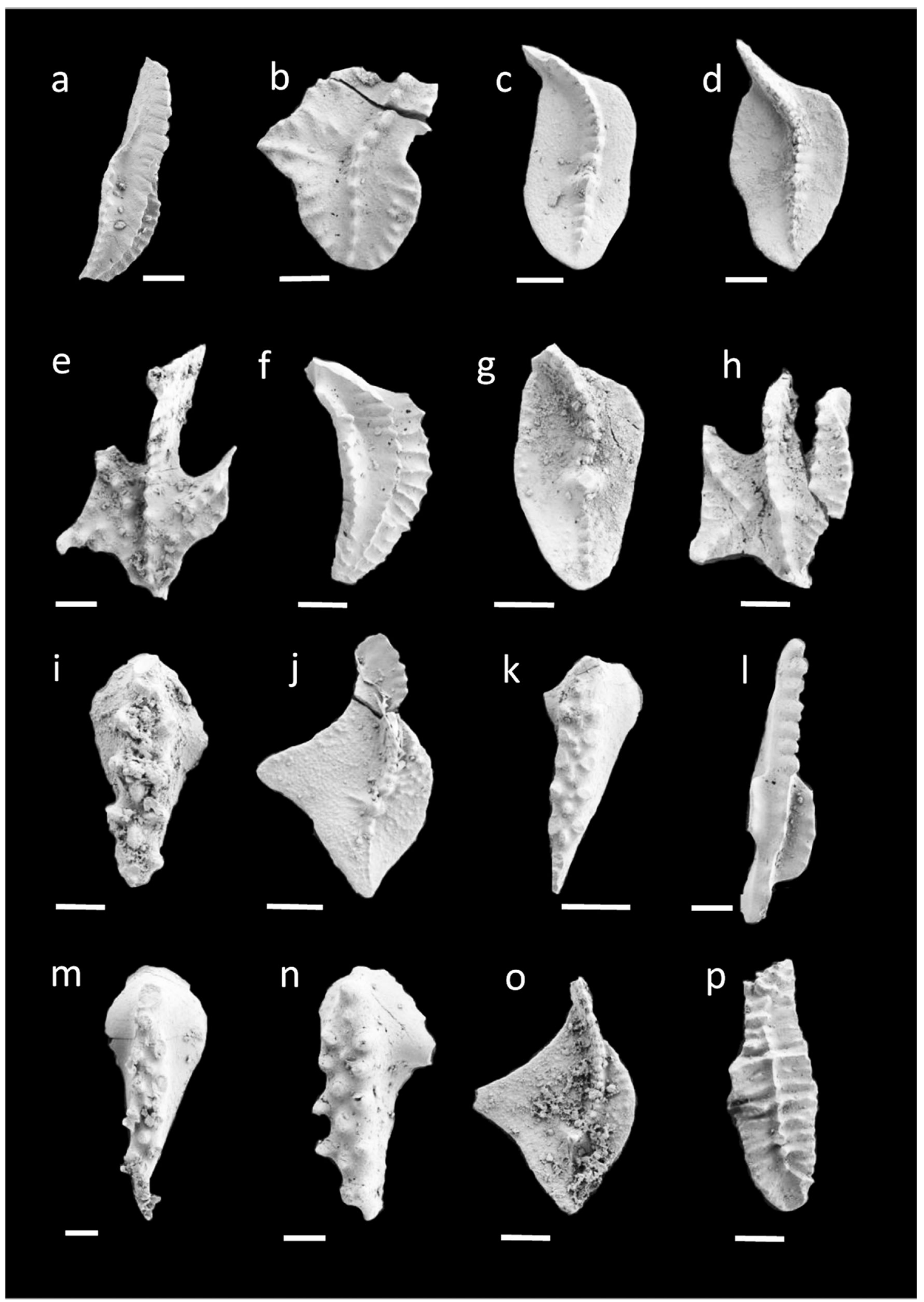

Fig. 7 Important conodonts of the Xom Nha section (scale bares $=100 \mu \mathrm{m}$ ): a Polygnathus tenellus (sample VN-XN-15); b Ancyrognathus seddoni (sample $\mathrm{VN}-\mathrm{XN}-16 \mathrm{~b}$ ); c Palmatolepis linguiformis (sample VN-XN-16b); d Palmatolepis linguiformis (sample VN-XN-17a); e Ancyrodella curvata (sample VN-XN-17a); f Polygnathus webbi (sample VN-XN-17a); g Palmatolepis linguiformis (sample VN-XN-18a); h Ancyrodella curvata (sample VN-XN-18a); i Icriodus alternatus alternatus (sample VN-XN-18a); j Palmatolepis triangularis (sample $\mathrm{VN}-\mathrm{XN}-18 \mathrm{~b}$ ); $\mathbf{k}$ Icriodus alternatus alternatus (sample VN-XN-18b); I Polygnathus brevilaminus (sample VN$\mathrm{XN}-18 \mathrm{~b}$ ); m Icriodus alternatus alternatus (sample VN-XN-19); n Icriodus alternatus helmsi (sample $\mathrm{VN}-\mathrm{XN}-19$ ); o Palmatolepis triangularis (sample $\mathrm{VN}-\mathrm{XN}-19$ ); p Ancyrognathus sinelaminus (sample VN-XN-21c) 


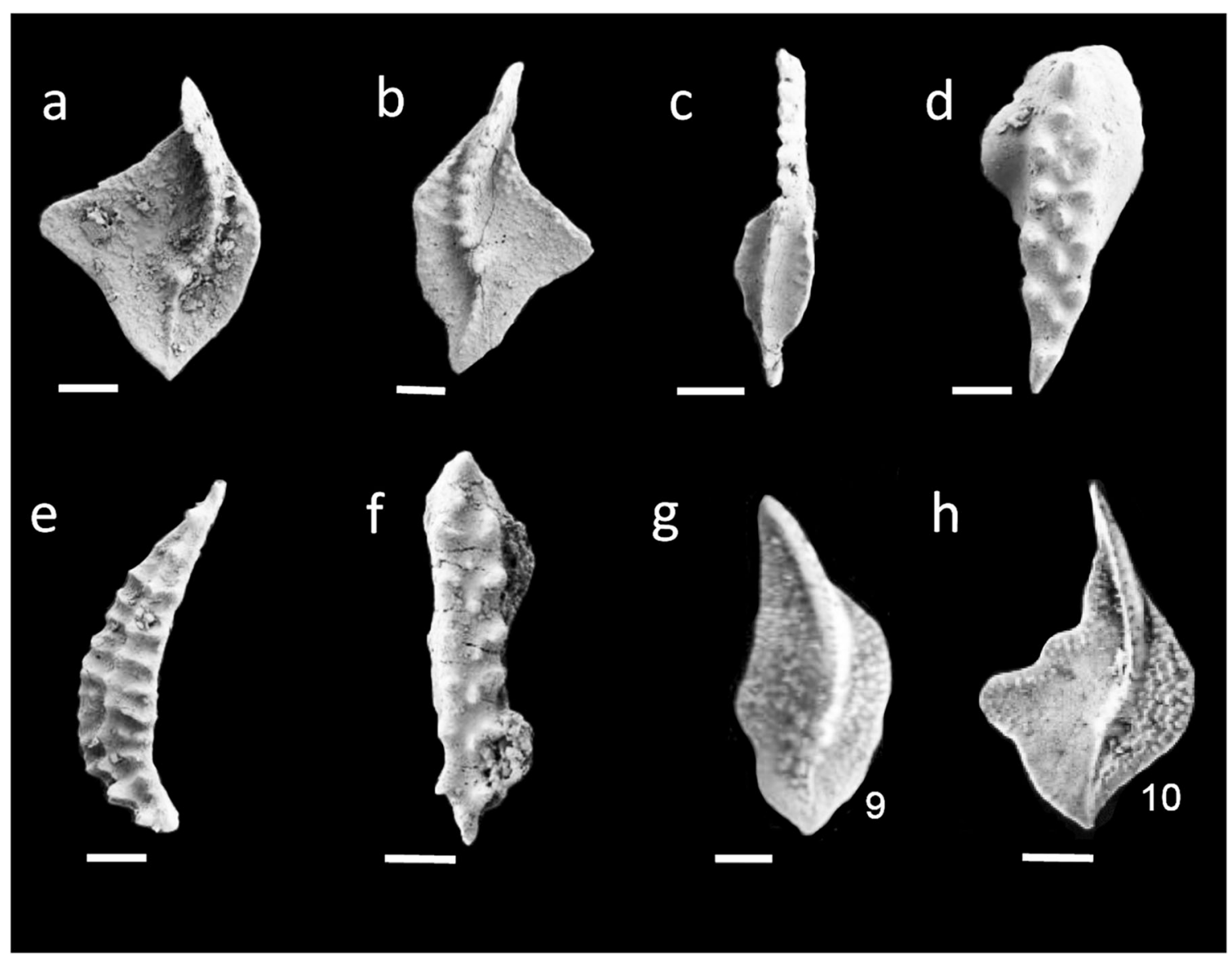

Fig. 8 Important conodonts of the Xom Nha section (scale bares $=100$ $\mu \mathrm{m})$ : a Palmatolepis cf. delicatula delicatula (sample VN-XN-21c); b Palmatolepis protorhomboidea (sample VN-XN-21c); c Polygnathus brevilaminus (sample $\mathrm{VN}-\mathrm{XN}-21 \mathrm{c}$ ); d Icriodus alternatus alternatus (sample VN-XN-21c); e Ancyrognathus sinelaminus (sample VN-XN-

shell concentrations occur in the limestone. Limestones have a thickness of several $\mathrm{cm}$ and show parallel bedding as well as graded bedding with a relatively sharp lower erosional surface. These limestones are covered by thin-bedded marls.

Interpretation: The fossiliferous limestones are interpreted to be deposited, in part, by distal turbidity currents and are typical of sediments found in basinal facies settings, such as lower slope facies sediments (Stow et al. 1996; Flügel 2004; Mulder 2011).

Conodont biostratigraphy and biofacies

\section{Conodont biostratigraphy (Table 1, Figs. 5, 6, 7 and 8)}

The results from the conodont stratigraphy in this section indicate that the upper part of the Xom Nha Formation ranges from the Palmatolepis hassi Zone to the Palmatolepis crepida Zone (Table 1). The crepida Zone is not shown in Figure 5, but this result is based on the earlier sampling (Ta Hoa 2002). Zonation scheme follows Ziegler and Sandberg (1990), and Ji and Ziegler (1993) for the Frasnian conodont stratigraphy, and Hartenfels 21c); f Icriodus alternatus helmsi (sample VN-XN-21c); g Palmatolepis crepida (sample X19, reillustrated from Ta Hoa (2002), figure II.4.18-9); h Palmatolepis quadrantinodosalobata (sample X20 reillustrated from Ta Hoa (2002), figure II.4.18-10)

(2011) and Spalletta et al. (2017) for the Famennian conodont stratigraphy. Although the Montagne Noire Zonation (MN; Klapper 1989; Girard et al. 2005) provides a more detailed stratigraphy in comparison to the Frasnian Standard Zonation (Ziegler and Sandberg 1990; Ji and Ziegler 1993), we used the latter for the Frasnian because the conodont collection did not yield all naming $\mathrm{MN}$ zonal species.

Conodont zones were indicated by either the First Appearance Datum (FAD) or the presence of distinct taxa. The distribution of important conodont taxa is shown in Table 1 and most zonal indicative species are provided in Figs 5, 6, 7 and 8. Overall, the conodonts are well preserved. The conodont alteration index (CAI, Epstein et al. 1977) has a range in the Xom Nha section between CAI 4.5 and CAI 5.

The Late Devonian Frasnian and Famennian conodonts from the Xom Nha section in Central Vietnam contain mainly cosmopolitan species. Most sampled beds yielded conodonts (ranging from $<10$ conodont elements per sample to $>300$ elements per sample). The conodont record in the Frasnian is generally very good whereas the record in the Famennian is scarce, which is not a result of different sample sizes because conodont samples 
weighting 1 to $1.5 \mathrm{~kg}$ were collected from all beds. The base of the Xom Nha section starts in the Palmatolepis hassi Zone. In sample VN-XN-1, the conodont collection is dominated by Palmatolepis hassi and Pa. punctata. Other important species are Ancyrodella lobata, and Ancyrodella buckeyensis, which have their first occurrence in the early part of the Palmatolepis hassi Zone (Ji and Ziegler 1993). Sample VN-XN-3 did not yield many conodonts, but yielded some important conodonts, including Ancyrognathus triangularis and Ancyrodella nodosa. The first appearance of Ancyrognathus triangularis defines the next younger Ancyrognathus triangularis Zone. The entry of Ancyrodella nodosa was used by Ji and Ziegler (1993) as an important species, which has its first appearance close to the beginning of the Late hassi Zone (= Ancyrognathus triangularis Zone). The base of the Ancyrognathus triangularis conodont zone can be correlated to the base of the MN 8 zonation defined by the FAD of Palmatolepis proversa (Klapper 1989). Palmatolepis proversa was not found in sample VN-XN-3, but did appear later in the section in sample $\mathrm{VN}-\mathrm{XN}-6$. Whether the later appearance of this species is linked to sampling bias or the range of this species is diachronous in respect to conodont records in other localities remains questionable. As shown by Dzik et al. (2018), who investigated the F/F boundary in northeastern Vietnam, it seems obvious that even very fast or subtle changes in environmental conditions find expressions in the fossil record of species. Overlying conodont samples (VN-XN-5, VN-XN-6) yielded species that represent diagnostic species to identify this zone, including Ancyrognathus triangularis, and Palmatolepis proversa. Other important associated conodonts include Palmatolepis hassi, Ancyrognathus primus, Ancyrodella nodosa, Ancyrodella curvata and Ancyrodella lobata (Table 1). The next younger conodont zone in sample VN-XN-7 is defined by the FAD of Palmatolepis jamieae and Ancyrodella ioides. The latter appears at or close to the start of the Palmatolepis jamieae Zone (Ziegler and Sandberg 1990). The overlying sample VN-XN-8 yielded conodonts which correspond to the Palmatolepis rhenana nasuta Zone, which is defined by the FAD of the name-giving species Palmatolepis rhenana nasuta. This conodont zone ranges from sample VN-XN-8 to VN-XN11. Important associated conodonts which were found in these samples are Palmatolepis hassi, Pa. jamieae, Pa. foliacea, $\mathrm{Pa}$. plana, Pa. unicornis, Ancyrodella nodosa, Anc. lobata, Anc. buckeyensis, Ancyrognathus triangularis, Polygnathus decorosus and Po. webbi among others. Palmatolepis feisti which defines the MN 11 Zone (Klapper 1989) was not found in the Xom Nha section. Icriodontids are scarce (Table 1).

The next younger Palmatolepis rhenana rhenana Zone ranges from sample VN-XN-12 to VN-XN 16a (Table 1). The base of this interval is well defined by the FAD of Palmatolepis rhenana rhenana. In addition, Palmatolepis subrecta occurred for the first time in that sample. Palmatolepis juntianensis occurred a little bit later in this zone in the Xom Nha section, and was found in sample VN-XN-13. Palmatolepis cf. bogartensis, which represents the MN 13a Zone (Klapper 1989), shows up in sample VN-XN-15b, below the Palmatolepis linguiformis Zone. The next younger Palmatolepis linguiformis Zone is clearly defined by the FAD of Palmatolepis linguiformis in sample VN-XN-16b (Table 1) where a large number of individuals of this species were found. It seems likely that in some areas in Asia this species is common. Savage (2013) also reported a relatively large number of $\mathrm{Pa}$. linguiformis from the Mae Sariang section in northwestern Thailand. The base of this conodont zone (Ziegler and Sandberg 1990; Ji and Ziegler 1993) corresponds to the MN Zone 13b of Girard et al. (2005). A further subdivision, suggested by Girard et al. (2005) (MN $13 \mathrm{c}=$ Ancyrognathus ubiquitus $)$, was not possible to define in our section due to a lack of this marker species.

The Frasnian/Famennian boundary of the Xom Nha section corresponds to the base of sample VN-XN-18b (Table 1) and is based on the FAD of Palmatolepis triangularis (Ziegler and Sandberg 1990). In our section, we could not define the Palmatolepis subperlobata Zone which corresponds to the lowest part of the former Lower triangularis Zone (Hartenfels 2011; Spalletta et al. 2017) defined by the FAD of Palmatolepis subperlobata. This species does not occur in our sample VN$\mathrm{XN}-18 \mathrm{~b}$, probably as a result of the scarcity of conodonts at that level. The conodont fauna shows low diversity, and Icriodus alternatus helmsi and Polygnathus brevilaminus were conodonts associated with this sample. The triangularis Zone (Hartenfels 2011; Spalletta et al. 2017) ranges from sample VN$\mathrm{XN}-18 \mathrm{a}$ to sample VN-XN-21a. The next younger section corresponds to the Middle triangularis Zone of Ziegler and Sandberg (1990) and can be correlated with the Palmatolepis delicatula platys Zone (Spalletta et al. 2017). The useful conodont species for the zonal identification in the absence of the marker species is Ancyrognathus sinelaminus which was found in sample VN-XN-21c (Figs. 7p and 8e). This species enters at the base of this zone (Spalletta et al. 2017). Palmatolepis delicatula platys was not found which may support the observation by Schülke (1995) who reported that this species is rather rare outside Europe. Savage (2013) reported a small number of this species from a F/F boundary section in Thailand but this species was also described from the Toc Tat Formation in Northern Vietnam by Komatsu et al. (2018). The lack of this species in our section might be a result of facies or insufficient sample size. Other associated conodonts in this sample are Palmatolepis protorhomboidea, Pa. triangularis, Icriodus alternatus helmsi, Icr. alternatus alternatus and Polygnathus webbi. Stratigraphically, the section reaches up into the Palmatolepis crepida Zone, which is not shown herein, but was reported by Ta Hoa (2007).

\section{Conodont biofacies}

Based on the relatively abundant conodont assemblage of the Xom Nha section, conodont biofacies (e.g. Sandberg 1976; 
Fig. 9 Conodont Stratigraphy and conodont biofacies of the Xom Nha section. $P a$. $=$ Palmatolepis, Po. $=$ Polygnathus, Anc. $=$ Ancyrognathus, Ad.$=$ Ancyrodella, and Icr. = Icriodus species
Stratigraphy

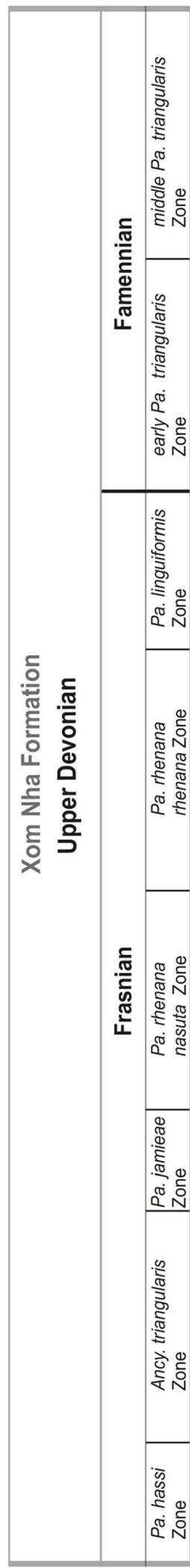

வீं ㄷำ
Lithology/sample number

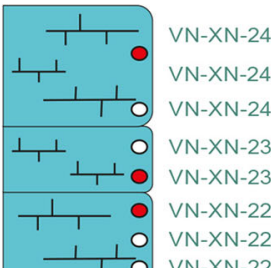

1,0 VN-XN-21d

71 O $V N-X N-210$

\begin{tabular}{lr|l}
1 & 10 \\
1 & 0 & $V N-X N-21 b$ \\
& & $V N-X N-21 a$
\end{tabular}

$\frac{1}{1}$ VN-XN-20b

$1_{1}^{1} \mathrm{VN}-\mathrm{XN}-20 \mathrm{a}$

$\perp, \perp$ । $\mathrm{V}$ VN-XN-19b

$\frac{1}{1}$ o $V N-X N-19 a$

$\frac{1}{1} 0$ VN-XN-18c

$\perp, 0 \quad V N-X N-18 b$

ITO VN-XN-18a

$\frac{1}{1} 0$ VN-XN-17b

$\stackrel{\perp, 1}{\perp}$,

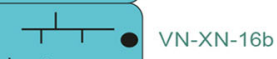

$\perp, 1$

$\mathrm{VN}-\mathrm{XN}-16 \mathrm{a}$

赵 กำ

$\frac{1}{1} \mathrm{VN}-\mathrm{XN}-15 \mathrm{~b}$

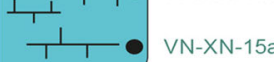

$\frac{1}{1}, V N-X N-14 b$

$T_{1} \mathrm{VN}-\mathrm{XN}-14 \mathrm{a}$

$\frac{1}{1}-V^{\prime}-\mathrm{XN}^{-13}$

$\frac{1}{1}=\mathrm{VN}-\mathrm{XN}-12$

$\frac{1}{1} \cdot \mathrm{VN}-\mathrm{XN}-11$

$\perp, \perp \perp_{1} \perp$

$\perp, \perp, 1,0$ VN-XN-10b

$\frac{1}{1} \cdot \mathrm{VN}-\mathrm{XN}-10 \mathrm{a}$

$I^{1} 10 v N-X N-9$

$\frac{1}{1}-\mathrm{VN}-\mathrm{XN}-\mathrm{B}$
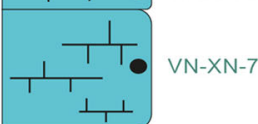

$\frac{1,1,1}{1+} \mathrm{VN}-\mathrm{XN}-6$

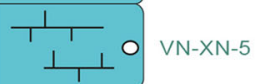

$\frac{1}{1} \circ \mathrm{VN}-\mathrm{XN}-4 \mathrm{~b}$

$\perp_{1} \perp_{0} \mathrm{VN}-\mathrm{XN}-4 \mathrm{a}$

VN-XN-3a

$\frac{1}{1}$ o $V N-X N-3$

\begin{tabular}{l|r|l} 
& 0 & $V N-X N-2 d$ \\
\hline & 10 & $V N-X N-2 c$
\end{tabular}

$I_{1}^{1} \mathrm{VN}-\mathrm{XN}-2 \mathrm{~b}$

$\frac{1}{T+1}\left\{\begin{array}{l}V N-X N-2 a \\ V N-X N-1\end{array} \quad 10\right.$ cm

Conodont biofacies

$0 \quad 100 \%$

scarce

conodonts

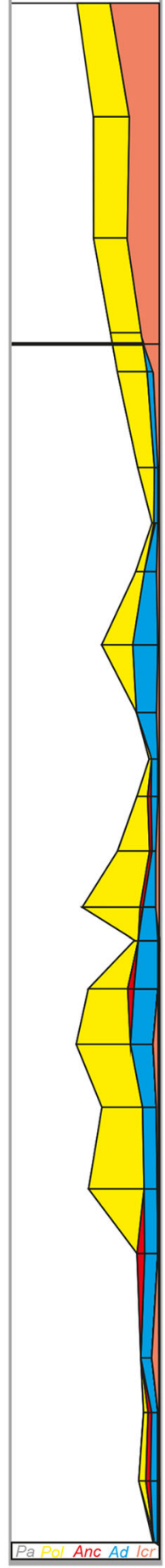

conodont record

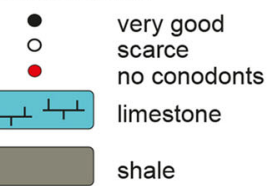

Xom Nha section

N $17^{\circ} 48^{\circ} 26,9^{\prime}$, E $105^{\circ} 56^{\prime} 41,1^{\prime}$ 
Fig. 10 Magnetic susceptibility data from the F/F boundary interval of the Xom Nha section, Vietnam (red line marks the age of the F/F boundary at 372.2 $\mathrm{Ma}$ - see www.stratigraphy.org.)

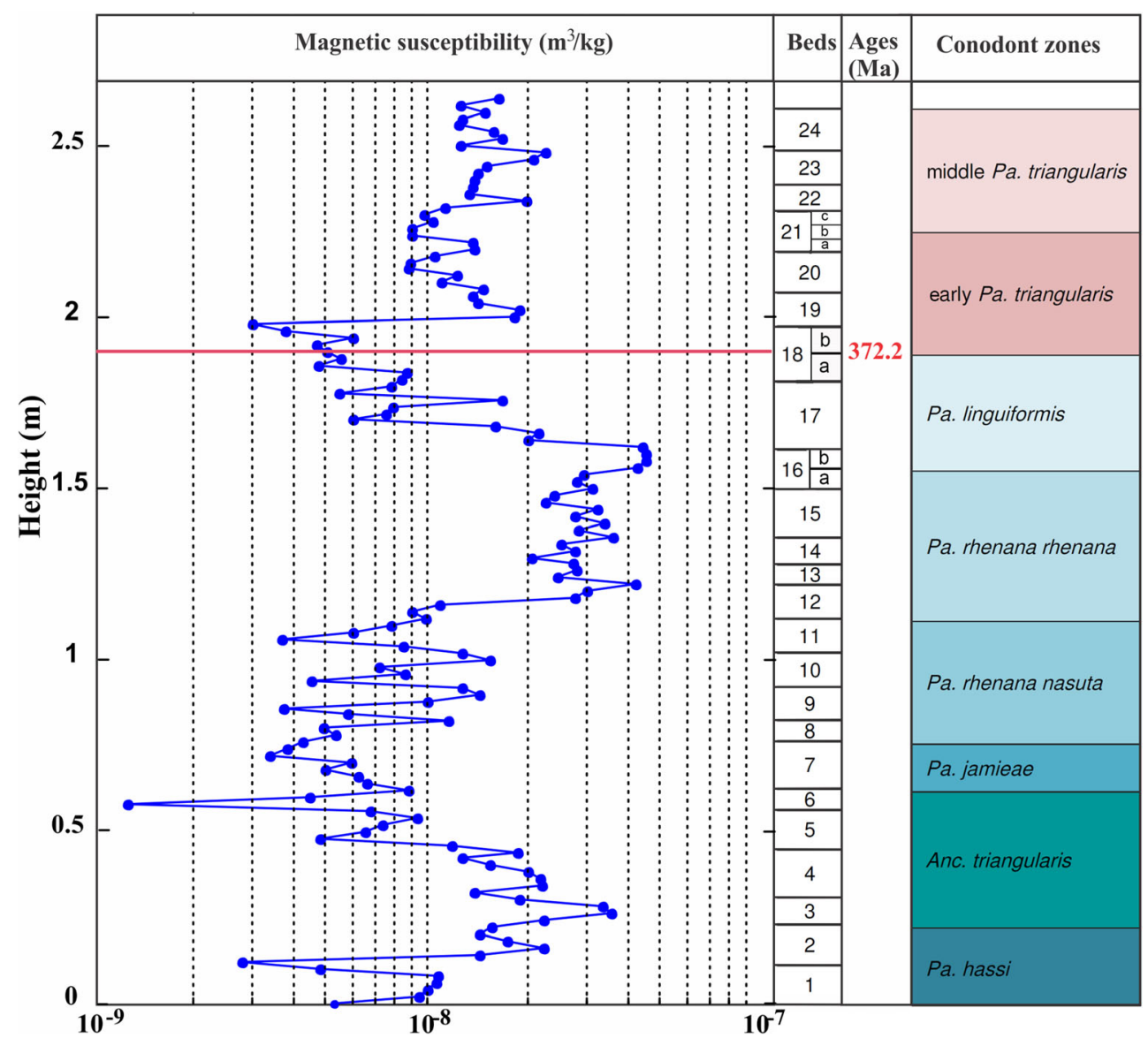

Weddige and Ziegler 1979; Sandberg and Ziegler 1979; Sandberg and Dreesen 1984; Sandberg et al. 1992) have been analysed. The whole section is mainly composed of lime mudstones and wackestones, suggesting an outer shelf environment below fair-weather wave base. Basically, the Xom Nha section is dominated by species of Palmatolepis and Polygnathus, which contain over $80 \%$ of the total P1 elements. Therefore, Palmatolepis elements exceed Polygnathus elements. Minor changes occur in some conodont zones (Table 1). The Frasnian part is generally dominated by a PalmatolepidPolygnathid biofacies. In the lower part of the Xom Nha section, comprising the Palmatolepis hassi and Ancyrognathus triangularis zones, Palmatolepis species are dominant and comprise over $90 \%$ of the P1 elements. Ancyrodella species occur in subordinate numbers and the specimens are less frequent. Icriodus and Polygnathus specimens are present, although never numerous. In the uppermost part of the Ancyrognathus triangularis Zone, the number of Polygnathus increases and continues through the Palmatolepis rhenana nasuta Zone that is associated with an increasing number of Ancyrodella specimens. At the base of the Palmatolepis rhenana rhenana Zone, conodont biofacies is dominated by Palmatolepis and Ancyrodella. Polygnathus species occur but are very scarce. A similar biofacies occurs at the top of this conodont zone (Fig. 9).
Within the Palmatolepis linguiformis Zone, the number of Polygnathus conodonts increases, and Icriodus specimens occur in small numbers below the F/F boundary. Icriodus specimens are present in some layers in the Frasnian, but they occur in very small numbers. In the Famennian, there is a marked increase of Icriodus and Polygnathus specimens, whereas the number of Palmatolepis specimens is observed to be decreasing. However, it should be noted that the total abundance of conodonts in the Famennian is scarce, particularly above sample VN-XN-22b. Thus, conodont biofacies analysis above this sample is not possible based on the present conodont record.

\section{Magnetic susceptibility}

From the $2.6 \mathrm{~m}$ thick Frasnian/Famennian Xom Nha section, 132 samples were collected for MS measurements and the MS data are given in Figure 10. The following interpretation convention for MS measurements is used. If the MS cyclic trends increase or decrease by a factor of two or more, and if the change is represented by two or more data points, then this change is assumed to be significant. This method is best employed when high-resolution data sets are being analysed (large numbers of closely spaced samples) and helps resolve variations associated with anomalous samples. Such variations may be due to weathering effects, secondary alteration and metamorphism. 
Fig. 11 MTM results show 2 major Milankovitch cycles exhibited in the MS data set: E2 (405 kyrs) and $\mathrm{O} 2$ (42 kyrs)
Xom Nha, time: 1215 kyears, SAR $=0.217 \mathrm{~cm} / \mathrm{kyr}$

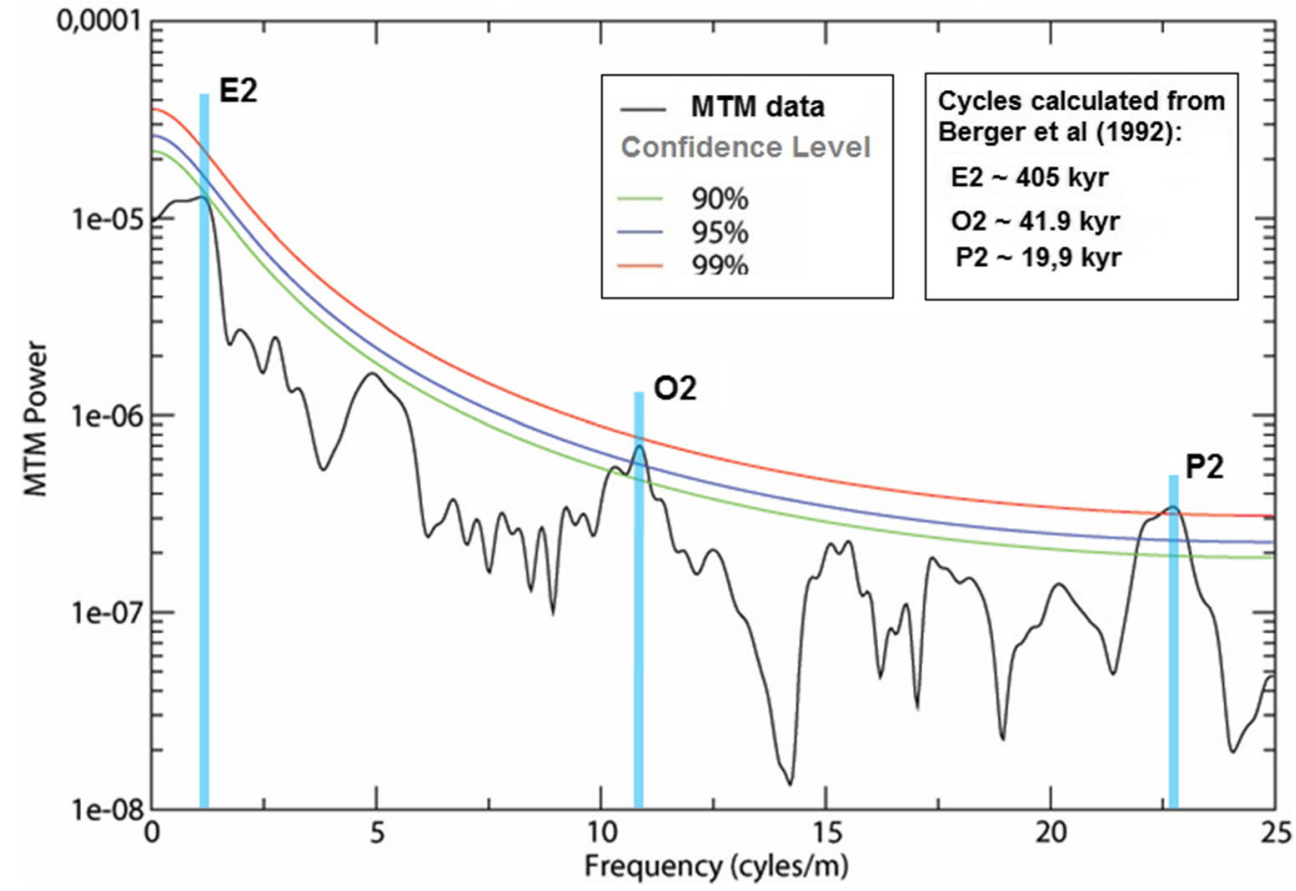

Longer-term trends are due to factors such as plate-driven eustacy, as opposed to shorter-term climate cycles, or event sequences such as impacts (Ellwood et al. 2004). In addition, variations in detrital input between localities, or a change in detrital sediment source, can often be compared between different localities. Abrupt MS shifts, such as that given at $2.0 \mathrm{~m}$ in Figure 10, may be interpreted as representing an unconformity, while cyclic trends are often interpreted as due to climate cycles, warm representing higher MS values due to erosion, while lows are generally due to cooler times with less rainfall and erosion. The Multi-Taper Method (MTM) uses MS data for time-series analysis (Fig. 11). The approach used here is to (a) collect closely and uniformly spaced samples in the field, (b) report MTM after normal detrending, (c) apply confidence limits to the MTM data, (d) place the important Milankovitch climate bands on the MTM diagrams for consistency checks and (e) establish a uniform model which can then be graphically compared to the MS cyclicity presented in Figure 10.

The MTM results show Milankovitch cycles with significant peaks. Using the work of Berger et al. (1992), we calculated two important climate cycles in the data set reported here, an eccentricity E2 (405 kyrs) cycle and an obliquity O2 (42 kyrs) cycle. Timing for the Xom Nha section is based on using the timeseries analysis presented here (Fig. 11). Using the timing presented in the International Chronostratigraphic Chart, 2018 version with $372.2 \mathrm{Ma}$ given for the F/F boundary (www. stratigraphy.org), we calculated the ages for the E2 and $\mathrm{O} 2$ main cycles for this section. From these results, we then calculated the interval of time represented by the MS samples in Figure 10 as $1.215 \mathrm{Ma}$. Therefore, the sediment accumulation rate $(\mathrm{SAR})=0.217 \mathrm{~cm} / \mathrm{kyrs}$ for the collected section (Fig. 10).

The spectral power for MS data sets presented here was obtained using the MTM method after the data were detrended and subjected to a Hanning window to reduce spectral leakage and increase the dynamic range in the data (Jenkins and Watts 1968; Thompson 1982). Incidences of high-confidence peaks at the 90, 95 and $99 \%$ confidence limits in the resulting spectra were determined by employing the MTM analysis (Ghil et al. 2002), as calculated using the SSA-MTM toolkit (Dettinger et al. 1995). A null hypothesis of red noise was assumed (low frequency and high power in the spectrum, sloping towards lower values at high frequencies), using a three-taper model. As this method is prone to producing false positives, the use of statistical significance is limited here to its role in supporting (or not) the positions of multiple Milankovitch bands within the MTM dataset. The positions of these bands are mathematically fixed relative to each other, and thus a climate-forcing mechanism is supported by spectral analysis when the Milankovitch frequencies are also frequencies of high spectral power, as is the case here.

\section{Conclusions}

The overall microfacies and faunal characteristics shown here point to relatively deep and quiet water in the aphotic zone below storm wave base or current activity in an hemipelagic palaeoenvironment. Interestingly, the Xom Nha section does not show the characteristic black shale/limestone lithology around the F/F boundary, which is known from other 
hemipelagic sections around the world (Carmichael 2019, and references therein). The occurrence of discontinuous surfaces is related to a combination of non-deposition or low sedimentation rates. The main sedimentary process is settling from suspended matter. Based on the data presented herein, a sediment accumulation rate of $0.217 \mathrm{~cm} / \mathrm{kyrs}$ was calculated. The conodont assemblage through the F/F boundary shows mainly cosmopoli$\tan$ species, which is similar to many sections elsewhere. However, the section measured here differs from most sections in Europe, because the Xom Nha section in Central Vietnam contains relatively high numbers of the species Palmatolepis linguiformis, which has also been described from sections in Thailand. Deposition through the F/F boundary interval reported here for the Xom Nha section appears to have occurred over a period of $\sim 1.2 \mathrm{Ma}$, and exhibits well-defined climate cyclicity.

\begin{abstract}
Acknowledgements Ta Hoa Phuong was supported by the National Foundation for Science and Technology (NAFOSTED project no. 105.03-2016.19). P. Königshof received funding by the German Science Foundation (DFG, KO 1622/15-1). Doan Dinh Hung was supported by the Project for Collecting Paleontological Specimens in Vietnam (BSTMV.28/15-18). Luu T. P. L. received funding by the VAST (NVCC12.01/21-21). Ellwood received funding from the Robie Clark endowment to LSU. We thank I. Boncheva (Technical University of Sofia, Bulgaria), an anonymous reviewer, for their constructive comments and suggestions. Furthermore, we thank Jana Anger (SenckenbergResearch Institute and Natural History Museum) for preparing thin sections and Hanna Cieszynski (University of Cologne, Institute of Geology and Mineralogy) for taking the REM photographs. This is a contribution to IGCP 652 "Reading geologic time in Palaeozoic sedimentary rocks" and IGCP 700 "Carbonate build-ups in Southeast Asia".
\end{abstract}

Funding Open Access funding enabled and organized by Projekt DEAL.

\section{Declarations}

Conflict of interest The authors declare that they have no conflict of interest.

Open Access This article is licensed under a Creative Commons Attribution 4.0 International License, which permits use, sharing, adaptation, distribution and reproduction in any medium or format, as long as you give appropriate credit to the original author(s) and the source, provide a link to the Creative Commons licence, and indicate if changes were made. The images or other third party material in this article are included in the article's Creative Commons licence, unless indicated otherwise in a credit line to the material. If material is not included in the article's Creative Commons licence and your intended use is not permitted by statutory regulation or exceeds the permitted use, you will need to obtain permission directly from the copyright holder. To view a copy of this licence, visit http://creativecommons.org/licenses/by/4.0/.

\section{References}

Algeo, T. J., \& Scheckler, S. E. (1998). Terrestrial-marine teleconnections in the Devonian: links between the evolution of land. Philosophical Transactions of The Royal Society, B
Biological Sciences, 353(1365), 113-130. https://doi.org/10.1098/ rstb.1998.0195.

Algeo, T. J., \& Scheckler, S. E. (2010). Land plant evolution and weathering rate changes in the Devonian. Journal of Earth Sciences, 21, 75-78. https://doi.org/10.1007/S12583-010-0173-2.

Berger, A., Loutre, M. F., \& Laskar, J. (1992). Stability of the astronomical frequencies over the Earth's history for paleoclimate studies. Science, 255, 560-566.

Bond, P. G. (2006). The fate of the homoctenids (Tentaculitoidea) during the Frasnian-Famennian mass extinction (Late Devonian). Geobiology, 4(3), 167-177. https://doi.org/10.1111/j.1472-4669. 2006.00078.x.

Carmichael, S. K., Waters, J. A., Suttner, T. J., Kido, E., \& DeReuil, A. A. (2014). A new model for the Kellwasser anoxia events (Late Devonian): shallow water anoxia in an open oceanic setting in the Central Asian Orogenic Belt. Palaeogeography, Palaeoclimatology, Palaeoecology, 399, 394-403. https://doi.org/10.1016/j.palaeo.2014. 02.016 .

Carmichael, S. K., Waters, J. A., Batchelor, C. J., Coleman, D. M., Suttner, T. J., Kido, E., Moore, L. M., \& Chadimová, L. (2016). Climate instability and tipping points in the Late Devonian: detection of the Hangenberg Event in an open oceanic island arc in the Central Asian Orogenic Belt. Gondwana Research, 32, 213-231. https://doi.org/10.1016/j.gr.2015.02.009.

Carmichael, S., Waters, J., Königshof, P., Suttner, T., \& Kido, E. (2019). Paleogeography and paleoenvironments of the Late Devonian Kellwasser Event: a review of its sedimentological and geochemical expression. Global and Planetary Change, 183, 102984. https://doi. org/10.1016/j.gloplacha.2019.102984.

Copper, P. (2002). Reef development at the Frasnian/Famennian mass extinction boundary. Palaeogeography, Palaeoclimatology, Palaeoecology, 181(1/3), 27-65.

Crônier, C., \& François, A. (2014). Distribution patterns of Upper Devonian phacopid trilobites: paleobiogeographical and paleoenvironmental significance. Palaeogeography, Palaeoclimatology, Palaeoecology, 404, $12-23$.

Dettinger, M. D., Ghil, M., Strong, C. M., Weibel, W., \& Yiou, P. (1995). Software expedites singular-spectrum analysis of noisy time series. Eos Transactions, 76(2), 12-21. https://doi.org/10.1029/ EO076i002p00012.

Dzik, J., Świś, P., \& Phong, N. D. (2018). The Frasnian-Famennian boundary in Vietnam and evolutionary meaning of FADs and LADs. Newsletters on Stratigraphy, 51(3), 327-342. https://doi. org $/ 10.1127 /$ nos $/ 2017 / 0418$.

Ellwood, B. B., \& Gose, W. L. (2006). Heinrich H1 and 8,200 Year B.P. Climate Events Recorded in Hall's Cave. Texas: Geology, 34, 753 756.

Ellwood, B. B., Peter, D. E., Balsam, W., \& Schieber, J. (1995). Magnetic and geochemical variations as indicators of paleoclimate and archaeological site evolution: examples from 41TR68. Fort Worth, Texas: Journal of Archaeological Science, 22, 409-415.

Ellwood, B.B., Petruso, K.M., \& Harrold, F.B. (1997). High-resolution paleoclimatic trends for the Holocene identified using magnetic susceptibility data from archaeological excavations in caves: Journal of Archaeological Science, 24, 569-573

Ellwood, B. B., Benoist, S. L., El Hassani, A., Wheeler, C., \& Crick, R. E. (2004). Response to comment on impact ejecta layer from the MidDevonian: possible connection to global mass extinctions. Science, 303, Technical Comment:471, 1-2.

Epstein, A. G., Epstein, J. B., \& Harris, L. D. (1977). Conodont color alteration - an index to organic metamorphism. Geological Survey of America, Professional Paper, 995, 1-27.

Flügel, E. (2004). Microfacies of Carbonate Rocks. Springer.

Gerecke, M., \& Schindler, E. (2012). "Time-specific facies" and biological crises: the Kellwasser Event interval near the Frasnian/ 
Famennian boundary (Late Devonian). Palaeogeography, Palaeoclimatology, Palaeoecology, 367-368, 19-29.

Ghil, M., Allen, M. R., Dettinger, M. D., Ide, K., Kondrashov, D., Mann, M. E., Robertson, A. W., Saunders, A., Tian, Y., Varadi, F., \& Yiou, P. (2002). Advanced spectral methods for climatic time series. Reviews of Geophysics, 40(1), 1-41. https://doi.org/10.1029/ 2000RG000092.

Girard, C., Klapper, G., \& Feist, R. (2005). Subdivision of the terminal Frasnian linguiformis conodont Zone, revision of the correlative interval of Montagne Noire Zone 13, and discussion of stratigraphically significant associated trilobites. Developments in Palaeontology and Stratigraphy, 20, 181-198. https://doi.org/10. 1016/S0920-5446(05)80007-X.

Hartenfels, S. (2011). Die globalen Annulata-Events und die DasbergKrise (Famennium, Oberdevon) in Europa und Nord-Afrika hochauflösende Conodonten-Stratigraphie, Karbonat-Mikrofazies, Paläoökologie und Paläodiversität. Münsterische Forschungen zur Geologie und Paläontologie, 105, 17-527.

Huang, C., \& Gong, Y. (2016). Timing and Patterns of the FrasnianFamennian Event: evidences from high-resolution conodont biostratigraphy and event-stratigraphy at the Yangdi section, Guangxi, South China. Palaeogeography, Palaeoclimatology, Palaeoecology, 448, 317-338. https://doi.org/10.1016/j.palaeo.2015.10.031.

Huang, C., Joachimski, M. M., \& Gong, Y. (2018a). Did climate changes trigger the Late Devonian Kellwasser Crisis? Evidence from a highresolution conodont $818 \mathrm{OPO} 4$ record from South China. Earth and Planetary Science Letters, 495, 174-184.

Huang, C., Song, J., Shen, J., \& Gong, Y. (2018b). The influence of the Late Devonian Kellwasser events on deep-water ecosystems: evidence from palaeontological and geochemical records from South China. Palaeogeography, Palaeoclimatology, Palaeoecology, 504, 60-74.

Jenkins, G. M., \& Watts, D. G. (1968). Spectral analysis and its applications. Holden-Day.

Ji, Q., \& Ziegler, W. (1993). The Lali section: an excellent reference section for Late Devonian in south China. Courier Forschungsinstitut Senckenberg, 157, 1-183.

Klapper, G. (1989). The Montagne Noire Frasnian (Upper Devonian) conodont succession. In N. J. McMillan, A. F. Embry, \& D. J. Glass (Eds.), Devonian of the World, Memoir 14 (Vol. 3, pp. 449468). Canadian Society of Petroleum Geologists.

Komatsu, T., Urakawa, R., Inada, T., Yamaguchi, K., Maekawa, T., Takashima, R., Williams, M., Nguyen, D. P., Doan, H. D., Nguyen, M. T., Niko, S., Tanaka, G., \& Yamaguchi, T. (2018). The Kellwasser events in the Upper Devonian Frasnian to Famennian transition in the Toc Tat Formation, northern Vietnam. Island Arc, 28, 1-17. https://doi.org/10.1111/iar.12281.

Königshof, P., Savage, N. M., Lutat, P., Sardsud, L., Dopieralska, J., Belka, Z., \& Racki, G. (2012). Late Devonian sedimentary record of the Paleotethys Ocean-the Mae Sariang section, northwestern Thailand. Journal of Asian Earth Sciences, 52, 146-157.

Königshof, P., Narkiewicz, K., Ta Hoa, P., Carmichael, S., \& Waters, J. (2017). Devonian Events: examples from the eastern Palaeotethys (Si Phai section, NE Vietnam). In B. Mottequin, L Slavík, \& P. Königshof (Eds.) Climate change and biodiversity patterns in the mid-Palaeozoic. Palaeobiodiversity and Palaeoenvironments, 97(3), 481-496. https://doi.org/10.1007/s12549-017-0272-5.

Lazăr, I., Grădinary, M., \& Petrescu, L. (2013). Ferruginous microstromatolites related to Middle Jurassic condensed sequences and hardgrounds (Bucegi Mountains, Southern Carpathians, Romania). Facies, 59, 359-390. https://doi.org/10.1007/s10347012-0313-5.

Ma, X. P., Sun, Y. L., Hao, W. C., \& Liao, W. H. (2002). Rugose corals and brachiopods across the Frasnian-Famennian boundary in central Hunan, Southe China. Acta Palaeontologica Polonica, 47(2), 373-396.
Ma, X., Gong, Y., Chen, D., Racki, G., Chen, X., \& Liao, W. (2016). The Late Devonian Frasnian-Famennian event in South China - patterns and causes of extinctions, sea level changes, and isotope variations. Palaeogeography, Palaeoclimatology, Palaeoecology, 448, 224 244.

McGhee, G. R. (1996). The Late Devonian mass extinction. New York, Columbia University Press, 378. https://doi.org/10.1038/npg.els. 0004177.

McLaren, D. J. (1982). Frasnian-Famennian extinctions. Geological Society of America Special Paper, 190, 447-484.

Mottequin, B., \& Poty, E. (2016). Kellwasser horizons, sea-level changes and brachiopod-coral crises during the late Frasnian in the NamurDinant Basin (southern Belgium): a synopsis. In R.T. Becker, P. Königshof, \& C.E. Brett (Eds.), Devonian climate, sea level and evolutionary events. Geological Society, London, Special Publications, 423, 235. https://doi.org/10.1144/SP423.6.

Mulder, T. (2011). Gravity processes on continental slope, rise and abyssal plains. In H. Hüneke \& T. Mulder (Eds.), Deep-Sea Sediments (pp. 25-148). Elsevier.

Olempska, E. (2002). The Late Devonian Upper Kellwasser event and entomozoacean ostracodes in the Holy Cross Mountains, Poland. Acta Palaentologica Polonica, 47, 247-266.

Racki, G. (2005). Toward understanding Late Devonian global events: few answers, many questions. In D.J. Over, J.R. Morrow, \& P.B. Wignall, (Eds.), Understanding Late Devonian and PermianTriassic Biotic and Climatic Events: Towards an Integrated Approach 20 5-36). https://doi.org/10.1016/S0920-5446(05) 80002-0.

Racki, G., Rakociński, M., \& Wignall, P. B. (2018). Mercury enrichments and the Frasnian-Famennian biotic crisis: a volcanic trigger proved? Geology, 46, 543-546. https://doi.org/10.1130/G40233.1.

Racki, G., Königshof, P., Belka, Z., Dopieralska, J., \& Pisarzowska, A. (2019). Diverse depositional and geochemical signature of the Frasnian-Famennian global event in the western Thailand, as a record of Palaeotethyan vs. Western Australian geotectonic affinities. Journal of Asian Earth Sciences, 2, 1-24. https://doi.org/10.1016/j. jaesx.2019.100010.

Raup, D. M., \& Sepkoski, J. J. (1982). Mass extinctions in the marine fossil record. Science, 215(4539), 1501-1503. https://doi.org/10. 1126/science.215.4539.1501.

Riquier, L., Trabovillard, N., Averbuch, O., Joachimski, M. M., Racki, G., Devleeschouwer, X., Albani, A. E., \& Riboulleau, A. (2005). Productivity and bottom water redox conditions at the FrasnianFamennian boundary on both sides of the Eovariscan Belt: constraints from trace-element geochemistry plants, weathering processes, and marine anoxic events. Developments in Palaeontology and Stratigraphy, 20, 199-224. https://doi.org/10.1016/S09205446(05)80008-1.

Riquier, L., Tribovillard, N., Averbuch, O., Devleeschouwer, X., \& Riboulleau, A. (2006). The Late Frasnian Kellwasser horizons of the Harz Mountains (Germany): two oxygen-deficient periods resulting from different mechanisms. Chemical Geology, 233(1), 137-155. https://doi.org/10.1016/j.chemgeo.2006.02.021.

Sandberg, C. A. (1976). Conodont biofacies of Late Devonian Polygnathus styriacus Zone in western United States. Geological Association of Canada-Special Paper, 15, 171-186.

Sandberg, C. A., \& Dreesen, R. (1984). Late Devonian icriodontid biofacies models and alternate shallow-water conodont zonation. The Geological Society of America, 196, 143-178. https://doi.org/ 10.1130/SPE196-p143.

Sandberg, C. A., \& Ziegler, W. (1979). Taxonomy and biofacies of important conodonts of Late Devonian styriacus-Zone, United States and Germany. Geologica et Palaeontologica, 13, 173-212.

Sandberg, C. A., Ziegler, W., Dreesen, R., \& Butler, J. L. (1992). Conodont biochronology, biofacies, taxonomiy, and event 
stratigraphy around the Middle Frasnian Lion Mudmound (F2h), Frasnes, Belgium. Courier Forschungsinstitut Senckenberg, 150, $1-87$.

Savage, N. M. (2013). Late Devonian conodonts from Northwestern Thailand (pp. 1-48). Trinity Press.

Schülke, I. (1995). Evolutive Prozesse bei Palmatolepis in der frühen Famenne-Stufe (Conodonta, Ober-Devon). Göttinger Arbeiten zur Geologie und Paläontologie, 67, 1-108.

Song, H. J., Algeo, T. J., Tong, J. N., Romaniello, S. J., Zhu, Y. Y., Chu, D. L., \& Anbar, A. D. (2017). Uranium and carbon isotopes document global-ocean redox-productivity relationships linked to cooling during the Frasnian-Famennian mass extinction. Geology, 45, 887-890. https://doi.org/10.1130/G39393.1.

Spalletta, C., Perri, M. C., Over, D. J., \& Corradini, C. (2017). Famennian (Upper Devonian) conodont zonation: revised global standard. Bulletin of Geosciences, 91, 31-57. https://doi.org/10.3140/bull. geosci.1623.

Stanley, S. M. (2016). Estimates of the magnitudes of major marine mass extinctions in Earth history. Proceedings of the National Academy of Sciences of the United States of America, 113, 6325-6334. https:// doi.org/10.1073/pnas1613094113.

Stearn, C. W. (1987). Effect of the Frasnian-Famennian extinction event on the stromaporoids. Geology, 15, 677-679.

Stow, D. A. V., Reading, H. G., \& Collinson, J. D. (1996). Deep seas. In H. G. Reading (Ed.), Sedimentary environments: Processes, Facies and Stratigraphy (pp. 395-453). Blackwell Science.

Streel, M., Caputo, M. V., Loboziak, S., \& Melo, J. H. G. (2000). Late Frasnian-Famennian climates based on palynomorph analyses and the question of the Late Devonian glaciations. Earth-Science Reviews, 52, 121-173.

Tạ Hoa, P. (2002). Devonian and Carboniferous conodont biostratigraphy of the Đồng Văn Section, Hà Giang Province. Journal of Geology, 19(20), 14-21.

Ta Hoa, P. (2007). Two Frasnian/Famennian boundary sections in Vietnam. VNU Journal of Science, Earth Science, 23, 137-146.

Tong-Dzuy Thanh, Vu Khuc, Dang Tran Huyen, Do Bat, Doan Nhat Truong, Nguyen Dich Dy, Nguyen Huu Hung, Pham Huy Thong, Pham Kim Ngan, Ta Hoa Phuong, Tran Huu Dan, Tran Tat Thang, Tran Van Trị, Trinh Van Long. 2006. Stratigraphical units of Vietnam. Vietnam National University Publishing House. Hanoi. 528

Thompson, D.J. (1982). Spectrum estimation and harmonic analysis. IEEE Proceedings, 70, 1055-1096.

Thompson, J.B., \& Newton, C.R. (1988). Late Devonian mass extinction Episodic cooling or warming? In N.J. McMillan, A.F. Embry, \& D.J. Glass (Eds.), Devonian of the World, Memoir 14 (Vol 3, pp. 29-34). Canadian Society of Petroleum Geologists.

Trần Văn Trị, Vũ Khúc, Bùi Minh Tâm, Cù Minh Hoàng, Đặng Trần Huyên, Đoàn Nhật Trưởng, Đỗ Bạt, Lê Đỗ Bình, Lê Đức An, Mai
Trọng Nhuận, Ngô Quang Toàn, Ngô Thường San, Nguyễn Bá Minh, Nguyễn Biểu, Nguyễn Địch Dỹ, Nguyễn Hữu Tý, Nguyễn Quang Hưng, Nguyễn Thành Vạn, Nguyễn Tuấn Phong, Nguyễn Văn Quý, Nguyễn Văn Vượng, Nguyễn Xuân Bao, Phạm Đức Lương, Phạm Kim Ngân, Phan Thiện, Phan Trọng Trịnh, Ta Hòa Phương, Trần Ngọc Nam, Trần Tân VĂn, Trần Tất Thắng, Trần Thanh Hải, Trần Trọng Hòa, Trần Tuấn Anh, Trịnh Văn Long, Võ Công Nghiệp (2011). Geology and Earth Resources of Viẹt Nam (pp. 1-646). Hanoi: Publishing House for Science and Tecnology.

Usuki, T., Lan, C. Y., Yui, T. F., Iizuka, Y., Van Tich, V., Tran, T. A., Okamoto, K., Wooden, J. L., \& Liou, J. G. (2009). Early Paleozoic medium-pressure metamorphism in Central Vietnam: evidence from SHRIMP U-Pb zircon ages. Geosciences Journal, 13(3), 245-256. https://doi.org/10.1007/s12303-009-0024-2.

Walliser, O.H. (1996). Global events in the Devonian and Carboniferous. In O.H, Walliser, (Eds.), Global Events and Event Stratigraphy in the Phanerozoic (pp. 225-250). Berlin: Springer.

Wang, K., Geldsetzer, H. H. J., Goodfellow, W. D., \& Krouse, H. R. (1996). The Late Devonian biotic crisis: impact theory revived? Acta Paleontologica Polonica, 41(4), 410-412.

Weddige, K., \& Ziegler, W. (1979). Evolutionary pattern in the conodont genera Polygnathus and Icriodus from the Middle Devonian. Geologica et Palaeontologica, 13, 157-164.

Wei, F., Gong, Y., \& Yang, H. (2012). Biogeography, ecology and extinction of Silurian and Devonian tentaculitoids. Palaeogeography Palaeoclimatology Palaeoecology, 358-360, 40-50. https://doi.org/ 10.1016/j.palaeo.2012.07.019.

Whalen, M.T. (2015). Chemostratigraphy and magnetic susceptibility of the Late Devonian Frasnian-Famennian transition in western Canada and southern China: implications for carbon and nutrient cycling and mass extinction. In A.C. Da Silva, M.T. Whalen, J. Hladil, L. Chadimova, D. Chen, S. Spassov F. Boulvain, \& X. Devleeschouwer (Eds.), Magnetic Susceptibility Application: A Window onto Ancient Environments and Climatic Variations. Geological Society London Special Publication 414, 37-72.

Wilson, J. L. (1975). Carbonate facies in geologic history (pp. 1-471). Heidelberg, New York: Springer.

Zatoń, M., Kremer, B., Marynowski, L., Wilson, M. A., \& Krawczyński, W. (2012). Middle Jurassic (Bathonian) encrusted oncoids from the Polish Jura, southern Poland. Facies, 58, 57-77. https://doi.org/10. 1007/s10347-011-0273-1.

Ziegler, W., \& Sandberg, C. A. (1990). The Late Devonian Standard Conodont Zonation. Courier Forschungsinstitut Senckenberg, 121 $1-115$.

Publisher's note Springer Nature remains neutral with regard to jurisdictional claims in published maps and institutional affiliations. 